Prepared for the U.S. Department of Energy

under Contract DE-AC05-76RL01830

\title{
ANSI/ASHRAE/IESNA Standard 90.1-2007 Final Qualitative Determination
}
M Halverson
E Richman
B Liu
D Winiarski

January 2011

Pacific Northwest

NATIONAL LABORATORY

Proudly Operated by Battelle Since 1965 


\title{
DISCLAIMER
}

This report was prepared as an account of work sponsored by an agency of the United States Government. Neither the United States Government nor any agency thereof, nor Battelle Memorial Institute, nor any of their employees, makes any warranty, express or implied, or assumes any legal liability or responsibility for the accuracy, completeness, or usefulness of any information, apparatus, produet, or process disclosed, or represents that its use would not infringe privately owned rights. Reference herein to any specific commercial product, process, or service by trade name, trademark, manufacturer, or otherwise does not necessarily constitute or imply its endorsement, recommendation, or favoring by the United States Government or any agency thereof, or Battelle Memorial Institute. The views and opinions of authors expressed herein do not necessarily state or reflect those of the United States Government or any agency thereof

\author{
PACIFIC NORTHWEST NATIONAL LABORATORY \\ operated by \\ BATTELLE \\ for the \\ UNITED STATES DEPARTMENT OF ENERGY \\ under Contract DE-AC0 5-76RL01830 \\ Printed in the United States of America \\ Available to DOE and DOE contractors from the \\ Office of Scientific and Technical Information, \\ P.O. Box 62, Oak Ridge, TN 37831-0062; \\ ph: (865) 576-8401 \\ fax: $(865) 576-5728$ \\ email: reports@adonis.osti.gov \\ Available to the public from the National Technical Information Service, \\ U.S. Department of Commerce, 5285 Port Royal Rd., Springfield, VA 22161 \\ ph: (800) $553-6847$
fax: $(703) 605-6900$ \\ email: orders $(a$ ntis.fedworld.gov \\ online ordering: http://www.ntis.gov/ordering.htm
}

(

This document was printed on recycled paper.

$(9 / 2003)$ 


\title{
ANSI/ASHRAE/IESNA Standard 90.1-2007 Final Qualitative Determination
}

\author{
M Halverson \\ E Richman \\ B Liu \\ D Winiarski
}

January 2011

Prepared for

the U.S. Department of Energy

under Contract DE-AC05-76RL01830

Pacific Northwest National Laboratory

Richland, Washington 99352 



\section{Summary}

A final qualitative analysis of all addenda to American National Standards Institute (ANSI)/American Society of Heating, Refrigerating and Air-Conditioning Engineers (ASHRAE)/Illuminating Engineering Society of North America (IESNA) Standard 90.1-2004 that were included in ANSI/ASHRAE/IESNA Standard 90.1-2007 was conducted. All 44 addenda processed by ASHRAE in the creation of Standard 90.1-2007 from Standard 90.1-2004 were evaluated by the U.S. Department of Energy (DOE) for their impact on energy efficiency. DOE preliminarily determined whether that addenda would have a positive, neutral, or negative impact on overall building efficiency. Table S.1 shows the number of positive and negative changes for each section of Standard 90.1.

The results of the textual analysis indicate that the majority of changes (30 of the total of 44 listed) were neutral. These include editorial changes, changes to reference standards, changes to alternative compliance paths, and other changes to the text of the standard that may improve the usability of the standard, but do not generally improve or degrade the energy efficiency of building. There were 11 changes that were evaluated as having a positive impact on energy efficiency and 2 changes that were evaluated as having a negative impact on energy efficiency.

The 2 negative impacts on energy efficiency include:

1. Addendum $\mathrm{p}$ - Expanded lighting power exceptions for use with the visually impaired

2. Addendum av - Allowance for louvered overhangs

The 11 positive impacts on energy efficiency include:

1. Addendum $\mathrm{c}-$ Increased requirement for building vestibules

2. Addendum $\mathrm{h}$ - Removal of data processing centers from exceptions to HVAC requirements

3. Addendum $\mathrm{q}-$ Removal of hotel room exceptions to HVAC requirements

4. Addendum $\mathrm{v}$ - Modification of demand controlled ventilation requirements

5. Addendum ac-Modification of fan power limitations

6. Addendum ai - Modification of retail display lighting requirements

7. Addendum ak - Modification of cooling tower testing requirements

8. Addendum an - Modification of commercial boiler requirements

9. Addendum ar-Modification of part load fan requirements

10. Addendum as - Modification of opaque envelope requirements

11. Addendum at - Modification of fenestration envelope requirements 
Table S.1. Results of Textual Analysis by Section of Standard 90.1

\begin{tabular}{|c|c|c|c|c|c|}
\hline Section of Standard & $\begin{array}{l}\text { Number of } \\
\text { Changes Made } \\
\text { to Section }\end{array}$ & $\begin{array}{l}\text { Number of } \\
\text { Positive (Energy } \\
\text { Saving) Changes }\end{array}$ & $\begin{array}{l}\text { Number of } \\
\text { Unquantifiable } \\
\text { Changes }\end{array}$ & $\begin{array}{l}\text { Number of Neutral } \\
\text { (No Energy Saving) } \\
\text { Changes }\end{array}$ & $\begin{array}{l}\text { Number of Negative } \\
\text { (Energy Increasing) } \\
\text { Changes }\end{array}$ \\
\hline $\begin{array}{l}\text { Title, Purpose, and } \\
\text { Scope }\end{array}$ & 0 & 0 & 0 & 0 & 0 \\
\hline Definitions & 0 & 0 & 0 & 0 & 0 \\
\hline $\begin{array}{l}\text { Administration and } \\
\text { Enforcement }\end{array}$ & 0 & 0 & 0 & 0 & 0 \\
\hline $\begin{array}{l}\text { Envelope and } \\
\text { Normative Appendices }\end{array}$ & 11 & 3 & 0 & 7 & 1 \\
\hline $\begin{array}{l}\text { HVAC Equipment and } \\
\text { Systems }\end{array}$ & 13 & 6 & 0 & 7 & 0 \\
\hline Service Water Heating & 0 & 0 & 0 & 0 & 0 \\
\hline Power & 0 & 0 & 0 & 0 & 0 \\
\hline Lighting & 9 & 2 & 1 & 5 & 1 \\
\hline $\begin{array}{l}\text { Energy Cost Budget } \\
\text { and Appendix G } \\
\text { Performance Rating } \\
\text { Method }\end{array}$ & 7 & 0 & 0 & 7 & 0 \\
\hline $\begin{array}{l}\text { Normative and } \\
\text { Informative } \\
\text { References }\end{array}$ & 4 & 0 & 0 & 4 & 0 \\
\hline Overall & 44 & 11 & 1 & 30 & 2 \\
\hline
\end{tabular}

Overall, the positive impacts outweigh the negative impacts in a simple numerical comparison. 


\section{Acronyms and Abbreviations}

$\begin{array}{ll}\text { ANSI } & \text { American National Standards Institute } \\ \text { ARI } & \text { Air-Conditioning and Refrigeration Institute } \\ \text { ASHRAE } & \text { American Society of Heating, Refrigerating and Air-Conditioning Engineers } \\ \text { ASTM } & \text { American Society for Testing and Materials } \\ \text { BECP } & \text { Building Energy Codes Program } \\ \text { bhp } & \text { brake horsepower } \\ \text { Btu } & \text { British thermal units } \\ \text { CFM } & \text { cubic feet per minute } \\ \text { CTI } & \text { Cooling Tower Institute } \\ \text { DOE } & \text { U.S. Department of Energy } \\ \text { ECB } & \text { energy cost budget } \\ \text { ft } & \text { square feet } \\ \text { hp } & \text { horsepower } \\ \text { h } & \text { hour(s) } \\ \text { HSPF } & \text { Heating Seasonal Performance Factor } \\ \text { HVAC } & \text { heating, ventilating, and air conditioning } \\ \text { IESNA } & \text { Illuminating Engineering Society of North America } \\ \text { NFRC } & \text { National Fenestration Rating Council } \\ \text { PNNL } & \text { Pacific Northwest National Laboratory } \\ \text { SDHV } & \text { small duct high velocity } \\ \text { SEER } & \text { Seasonal Energy Efficiency Ratio } \\ \text { SHGC } & \text { solar heat gain coefficient } \\ \text { SRI } & \text { Solar Reflectance Index } \\ \text { VAV } & \text { variable air volume } \\ \text { WWR } & \text { window-to-wall ratio } \\ & \end{array}$





\section{Contents}

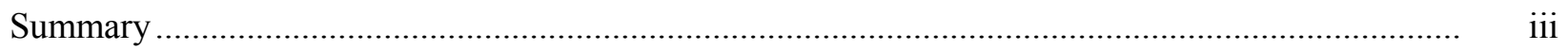

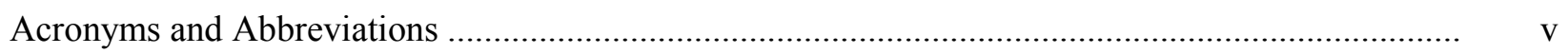

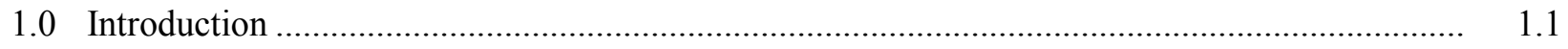

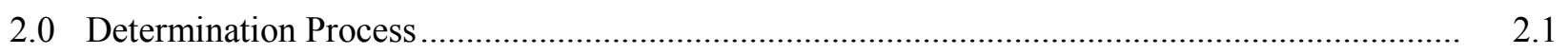

3.0 Identification of Addenda in Standard 90.1-2007 ...............................................................

4.0 Evaluation of Energy Efficiency Impacts of Addenda in Standard 90.1-2007......................... 4.1

5.0 Detailed Discussion of Impacts of Addenda on Various Sections of Standard 90.1-2007......... $\quad 5.1$

5.1 Changes to Section 1, Purpose .................................................................................... 5.1

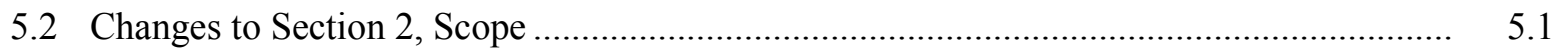

5.3 Changes to Section 3, Definitions, Abbreviations, and Acronyms …............................... 5.1

5.4 Changes to Section 4, Administration and Enforcement................................................. 5.1

5.5 Changes to Section 5, Building Envelope and Normative Appendices A-D .................... 5.1

5.6 Changes to Section 6, Heating, Ventilating, and Air-Conditioning .................................. 5.4

5.7 Changes to Section 7, Service Water Heating............................................................... 5.7

5.8 Changes to Section 8, Power....................................................................................... 5.7

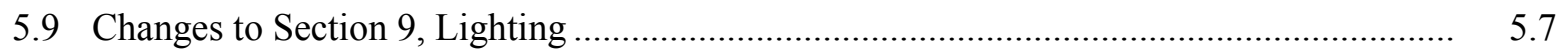

5.10 Changes to Section, 10 Other Equipment ..................................................................... 5.9

5.11 Changes to Section 11, Energy Cost Budget Method .................................................. 5.9

5.12 Changes to Section 12, Normative References ................................................................ 5.10

5.13 Changes to Informative Appendix E, Informative References ........................................ 5.10

5.14 Changes to Informative Appendix F, Addenda Description Information .......................... 5.10

5.15 Changes to Informative Appendix G, Performance Rating Method ................................. 5.10

6.0 Evaluation of Addenda by Topic and for Inclusion in the Quantitative Analysis ...................... 6.1

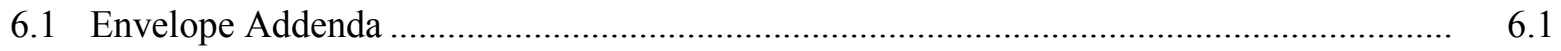

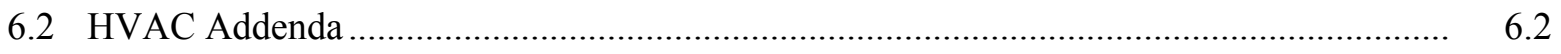

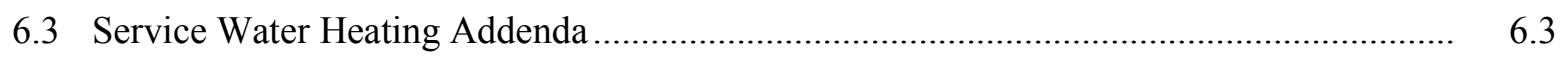

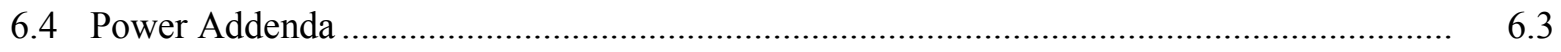

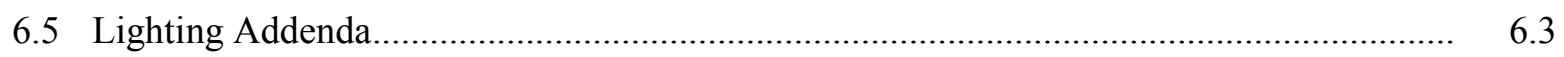

6.6 Other Equipment Addenda..................................................................................... 6.3

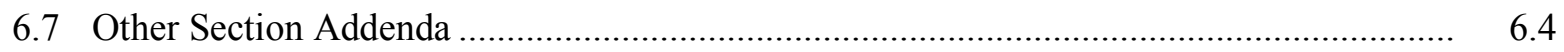

Appendix A - Detailed Evaluation of Addenda as and at for Building Envelope ............................ A.1 


\section{Tables}

3.1 Addenda to ASHRAE Standard 90.1-2004, Changes Identified ............................................. 3.2

4.1 Summary of Differences between Standards 90.1-2004 and 90.1-2007, by Addenda ................ 4.2

4.2 Overall Summary of Addenda Impact Overall Impact of Addenda ........................................... 4.9

4.3 Results of Textual Analysis by Section of Standard 90.1 ........................................................ 4.9

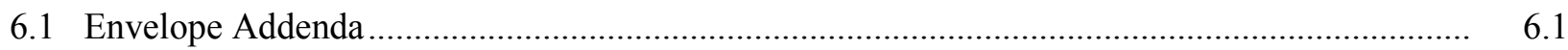

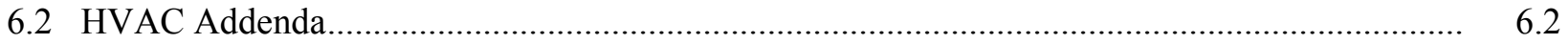

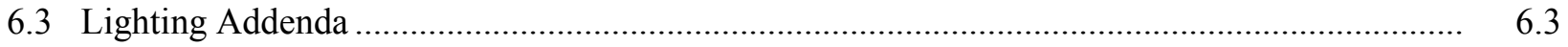

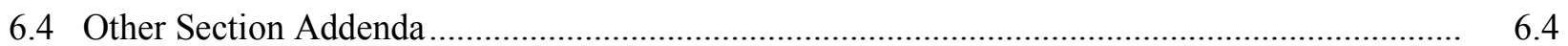




\subsection{Introduction}

In support of the U.S. Department of Energy's (DOE) final determination of energy savings of American National Standards Institute (ANSI)/American Society of Heating, Refrigerating and AirConditioning Engineers (ASHRAE)/Illuminating Engineering Society of North America (IESNA) Standard 90.1-2007 (ASHRAE 90.1-2007), staff from Pacific Northwest National Laboratory's (PNNL) Building Energy Codes Program (BECP) have prepared this analysis of changes made to Standard 90.1 between ANSI/ASHRAE/IESNA Standard 90.1-2004 (ASHRAE 90.1-2004) and ASHRAE Standard 90.1-2007 (ASHRAE 90.1-2007). ASHRAE processes changes to Standard 90.1 in the form of individual addendums, with each addendum representing a single change or set of changes related topically or chronologically. Addenda may range from a few words changed for clarification to complete replacement of a series of requirements tables.

On September 3, 2010, DOE issued a preliminary determination that Standard 90.1-2007 would achieve greater energy efficiency in buildings subject to the code, than the 2004 edition (Standard 90.12004 or the 2004 edition). Accompanying that determination were two PNNL documents detailing the qualitative $^{1}$ and quantitative ${ }^{2}$ analyses that fed into the determination. Comments were accepted on the preliminary determination until October 4, 2010. No comments were received on qualitative or quantitative reports. The preliminary qualitative report provided the basis of this report.

\footnotetext{
${ }^{1}$ Halverson, M, B Liu, E Richman, and D Winiarski. May 2010. ANSI/ASHRAE/IESNA Standard 90.1-2007 Preliminary Qualitative Determination. Pacific Northwest National Laboratory. PNNL-19791

${ }^{2}$ Halverson, M, B Liu, E Richman, and D Winiarski. May 2010. ANSI/ASHRAE/IESNA Standard 90.1-2007 Preliminary Determination Quantitative Analysis. Pacific Northwest National Laboratory. PNNL-19789
} 



\subsection{Determination Process}

DOE typically requests two types of analysis from BECP in a determination of energy savings on Standard 90.1. The first type is a qualitative analysis that attempts to identify all the changes made to the older version of Standard 90.1 to create the revised standard and then categorize the changes as having a positive, negative, or neutral impact on energy efficiency in Standard 90.1. No attempt is made to estimate the actual impact using whole building simulation in the qualitative analysis. Three steps are typically undertaken in the qualitative analysis. The first step is to identify all changes made to Standard 90.1. The second step is to qualitatively estimate the impact of each change on the energy efficiency of Standard 90.1. The third step is to look at the changes and categorize them into those that have a clear impact on stringency of requirements in the standard, and of these, those that can be incorporated in DOE's quantitative analysis and those that cannot be readily incorporated into DOE's quantitative analysis.

The second type of analysis that BECP performs for DOE is the quantitative analysis of energy savings on Standard 90.1. This analysis uses the results of the qualitative analysis to identify what changes should be incorporated into the building models used for whole building simulation. 



\subsection{Identification of Addenda in Standard 90.1-2007}

Table 3.1 contains the complete list of addenda processed by ASHRAE for ANSI/ASHRAE/IESNA Standard 90.1-2007. A total of 44 addenda to 90.1-2004 exist. All addenda were applied to ASHRAE Standard 90.1-2004 to create ASHRAE Standard 90.1-2007. The following list is taken from Appendix F to ASHRAE Standard 90.1-2007. ASHRAE/IESNA Standard 90.1-2007 incorporates ASHRAE Standard 90.1-2004 and Addenda a, b, c, d, e, f, g, h, i, j, k, 1, m, n, o, p, q, r, s, t, u, v, x, y, aa, ab, ac, ad, ae, af, ag, ah, ai, aj, ak, al, am, an, ap, aq, ar, as, at, and av to ASHRAE Standard 90.1-2004. Table 3.1 lists each addendum, describes how the text is affected by the change, and provides ASHRAE, IESNA, and ANSI approval dates.

Appendix F to ASHRAE Standard 90.1-2007 does contain two typographical errors in the description of addendum ae. The first error is that this addendum does not address Section 9, Lighting. The changes made in addendum ae were lighting related but were made to Section 11, Energy Cost Budget Method, and Appendix G, Performance Rating Method. The second error is that addendum ae does not address space control issues, but rather clarifies that the average lighting power density for each thermal block should be modeled. These typographical errors have been corrected in Table 3.1, below, so Table 3.1 is no longer identical to the table found in Appendix F of ASHRAE Standard 90.1-2007. Some additional

wording has also been added to Table 3.1 to clarify the description of the addenda found in Appendix $F$ to Standard 90.1-2007.

Appendix F also contains a typographical error in that two addenda (as and at) are not included in the list of addenda provided in the first sentence of the text of the appendix. These addenda are included in the table that accompanies the text and represent changes incorporated in ASHRAE Standard 90.1-2007 
Table 3.1. Addenda to ASHRAE Standard 90.1-2004, Changes Identified

\begin{tabular}{|c|c|c|c|c|c|c|}
\hline $\begin{array}{c}\text { Addenda to } \\
90.1-2004\end{array}$ & Section(s) Affected & Description of Changes & $\begin{array}{l}\text { ASHRAE } \\
\text { Standards } \\
\text { Committee } \\
\text { Approval Date }\end{array}$ & $\begin{array}{c}\text { ASHRAE } \\
\text { Board of } \\
\text { Directors } \\
\text { Approval } \\
\text { Date }\end{array}$ & $\begin{array}{l}\text { IESNA } \\
\text { Approval } \\
\text { Date }\end{array}$ & $\begin{array}{l}\text { ANSI } \\
\text { Approval } \\
\text { Date }\end{array}$ \\
\hline $90.1 \mathrm{a}$ & Informative Appendix G & $\begin{array}{l}\text { This addendum clarifies how windows should be distributed in the baseline } \\
\text { simulation model,clarifies how uninsulated assemblies should be treated in } \\
\text { the baseline simulation model, increases the size range for the use of } \\
\text { packaged VAV systems in the baseline model, and provides more detail on } \\
\text { how service hot-water systems should be modeled. Many of these changes } \\
\text { may affect the ultimate performance rating of buildings using Appendix G. In } \\
\text { addition, a reference was added to ASHRAE Standard } 140 \text { establishing the } \\
\text { method of testing of building energy simulation software. }\end{array}$ & $1 / 21 / 06$ & $1 / 26 / 06$ & $1 / 18 / 06$ & $4 / 10 / 06$ \\
\hline $90.1 b$ & $\begin{array}{l}\text { 6. Heating, Ventilating, } \\
\text { and Air Conditioning }\end{array}$ & $\begin{array}{l}\text { Revises Table } 6.8 .1 \mathrm{D} \text { and adds a definition for single-package vertical air- } \\
\text { conditioner and single-package vertical heat pump. }\end{array}$ & $6 / 25 / 05$ & $6 / 30 / 05$ & $8 / 3 / 05$ & $8 / 3 / 05$ \\
\hline $90.1 \mathrm{c}$ & 5. Building Envelope & $\begin{array}{l}\text { This addendum revises the definition of building entrance to include } \\
\text { vestibules and clarifies the requirements and exceptions for vestibules in } \\
\text { Section 5.4.3.4. }\end{array}$ & $6 / 25 / 05$ & $6 / 30 / 05$ & $8 / 3 / 05$ & $8 / 3 / 05$ \\
\hline $90.1 d$ & 12. Normative References & $\begin{array}{l}\text { This addendum updates the references applicable to the building envelope and } \\
\text { deletes references that are not cited in the standard. }\end{array}$ & $6 / 25 / 05$ & $6 / 30 / 05$ & $8 / 3 / 05$ & $8 / 3 / 05$ \\
\hline $90.1 \mathrm{e}$ & 9. Lighting & $\begin{array}{l}\text { This addendum recognizes that track and busway type lighting systems can be } \\
\text { limited by circuit breakers and permanently installed current limiters in } \\
\text { Section 9.1.4. }\end{array}$ & $6 / 25 / 05$ & $6 / 30 / 05$ & $8 / 3 / 05$ & $8 / 3 / 05$ \\
\hline $90.1 \mathrm{f}$ & $\begin{array}{l}\text { 6. Heating, Ventilating, } \\
\text { and Air Conditioning }\end{array}$ & $\begin{array}{l}\text { This addendum modifies Tables } 6.8 .1 \mathrm{~A} \text { and } 6.8 .1 \mathrm{~B} \text { by raising the minimum } \\
\text { efficiency for three-phase air-cooled central conditioners and heat pumps to } \\
\text { be consistent with federal minimum standards. }\end{array}$ & $1 / 21 / 06$ & $1 / 26 / 06$ & $1 / 18 / 06$ & $4 / 10 / 06$ \\
\hline $90.1 \mathrm{~g}$ & $\begin{array}{l}\text { 6. Heating, Ventilating, } \\
\text { and Air Conditioning }\end{array}$ & $\begin{array}{l}\text { This addendum amends the minimum efficiency levels of air-cooled air } \\
\text { conditioners and heat pumps in Tables 6.8.1 A and 6.8.1B to be consistent } \\
\text { with federal minimum standards. }\end{array}$ & $1 / 21 / 06$ & $1 / 26 / 06$ & $1 / 18 / 06$ & $4 / 10 / 06$ \\
\hline $90.1 \mathrm{~h}$ & $\begin{array}{l}\text { 6. Heating, Ventilating, } \\
\text { and Air Conditioning }\end{array}$ & $\begin{array}{l}\text { This addendum revises the exceptions to Sections } 6.4 .3 .1 .2 \text { and } 6.4 .3 .6 \text { by } \\
\text { removing specific exceptions on temperature and humidification dead bands } \\
\text { for data processing centers. }\end{array}$ & $1 / 21 / 06$ & $1 / 26 / 06$ & $1 / 18 / 06$ & $4 / 10 / 06$ \\
\hline
\end{tabular}




\begin{tabular}{|c|c|c|c|c|c|c|}
\hline $\begin{array}{l}\text { Addenda to } \\
\text { 90.1-2004 }\end{array}$ & Section(s) Affected & Description of Changes & $\begin{array}{l}\text { ASHRAE } \\
\text { Standards } \\
\text { Committee } \\
\text { Approval Date }\end{array}$ & $\begin{array}{c}\text { ASHRAE } \\
\text { Board of } \\
\text { Directors } \\
\text { Approval } \\
\text { Date }\end{array}$ & $\begin{array}{l}\text { IESNA } \\
\text { Approval } \\
\text { Date }\end{array}$ & $\begin{array}{c}\text { ANSI } \\
\text { Approval } \\
\text { Date }\end{array}$ \\
\hline $90.1 \mathrm{i}$ & 9. Lighting & $\begin{array}{l}\text { This addendum adds language to Section } 9.1 .4(\mathrm{~b}) \text { that allows additional } \\
\text { flexibility in assigning wattage to luminaires with multi-level ballasts where } \\
\text { other luminaire components would restrict lamp size. }\end{array}$ & $1 / 21 / 06$ & $1 / 26 / 06$ & $1 / 18 / 06$ & $4 / 10 / 06$ \\
\hline $90.1 \mathrm{j}$ & 9. Lighting & $\begin{array}{l}\text { This addendum to Section 9.4.1.3 allows additional flexibility in complying } \\
\text { with the controls requirements by allowing additional combinations of } \\
\text { commonly available control equipment. }\end{array}$ & $1 / 21 / 06$ & $1 / 26 / 06$ & $1 / 18 / 06$ & $4 / 10 / 06$ \\
\hline $90.1 \mathrm{k}$ & Informative Appendix A & $\begin{array}{l}\text { This addendum revises Table A2.3 to add U-factors for screw-down roofs } \\
\text { with R-19 insulation. }\end{array}$ & $1 / 21 / 06$ & $1 / 26 / 06$ & $1 / 18 / 06$ & $4 / 10 / 06$ \\
\hline 90.11 & 12. Normative References & This addendum updates the reference to ASHRAE Standard 140. & $1 / 21 / 06$ & $1 / 26 / 06$ & $1 / 18 / 06$ & $4 / 10 / 06$ \\
\hline $90.1 \mathrm{~m}$ & 9. Lighting & $\begin{array}{l}\text { This addendum revises the exception to Section } 9.2 .2 .3 \text { to provide an option } \\
\text { for compliance that exempts the commonly used furniture mounted track } \\
\text { lighting if it incorporates automatic shutoff. }\end{array}$ & $1 / 21 / 06$ & $1 / 26 / 06$ & $1 / 18 / 06$ & $4 / 10 / 06$ \\
\hline $90.1 \mathrm{n}$ & 5. Building Envelope & $\begin{array}{l}\text { This addendum revises Section 5.5.4.4.1 to provide an exception to allow a } \\
\text { user to take credit for partially opaque overhangs towards compliance with the } \\
\text { maximum SHGC requirements. }\end{array}$ & $1 / 21 / 06$ & $1 / 26 / 06$ & $1 / 18 / 06$ & $4 / 10 / 06$ \\
\hline 90.10 & Normative Appendix D & $\begin{array}{l}\text { This addendum increases the amount of international climatic data in } \\
\text { Appendix D. }\end{array}$ & $1 / 21 / 06$ & $1 / 26 / 06$ & $1 / 18 / 06$ & $4 / 10 / 06$ \\
\hline $90.1 \mathrm{p}$ & 9. Lighting & $\begin{array}{l}\text { This addendum modifies Exception }(\mathrm{g}) \text { to Section 9.2.2.3 to allow for } \\
\text { increased lighting for medical- and age-related issues in addition to visual } \\
\text { impairment. }\end{array}$ & $1 / 21 / 06$ & $1 / 26 / 06$ & $1 / 18 / 06$ & $4 / 10 / 06$ \\
\hline $90.1 q$ & $\begin{array}{l}\text { 6. Heating, Ventilating, } \\
\text { and Air Conditioning }\end{array}$ & $\begin{array}{l}\text { This addendum removes Exception (a) to Section } 6.4 .3 .2 \text { for HVAC systems } \\
\text { serving hotel/motel rooms and guest rooms. }\end{array}$ & $1 / 21 / 06$ & $1 / 26 / 06$ & $1 / 18 / 06$ & $4 / 10 / 06$ \\
\hline $90.1 \mathrm{r}$ & 12. Normative References & $\begin{array}{l}\text { This addendum updates the reference to ARI } 340 / 260 \text { from the } 2000 \text { edition } \\
\text { to the } 2004 \text { edition. }\end{array}$ & $1 / 21 / 06$ & $1 / 26 / 06$ & $1 / 18 / 06$ & $4 / 10 / 06$ \\
\hline $90.1 \mathrm{~s}$ & $\begin{array}{l}\text { 6. Heating, Ventilating, } \\
\text { and Air Conditioning and } \\
\text { 12. Normative References }\end{array}$ & $\begin{array}{l}\text { This addendum updates language in the standard based on differences } \\
\text { between Standard 62-1999 and 62.1-2004. The reference has also been } \\
\text { updated. }\end{array}$ & $1 / 21 / 06$ & $1 / 26 / 06$ & $1 / 18 / 06$ & $4 / 10 / 06$ \\
\hline
\end{tabular}




\begin{tabular}{|c|c|c|c|c|c|c|}
\hline $\begin{array}{l}\text { Addenda to } \\
\text { 90.1-2004 }\end{array}$ & Section(s) Affected & Description of Changes & $\begin{array}{l}\text { ASHRAE } \\
\text { Standards } \\
\text { Committee } \\
\text { Approval Date }\end{array}$ & $\begin{array}{c}\text { ASHRAE } \\
\text { Board of } \\
\text { Directors } \\
\text { Approval } \\
\text { Date }\end{array}$ & $\begin{array}{l}\text { IESNA } \\
\text { Approval } \\
\text { Date }\end{array}$ & $\begin{array}{l}\text { ANSI } \\
\text { Approval } \\
\text { Date }\end{array}$ \\
\hline $90.1 \mathrm{t}$ & $\begin{array}{l}\text { 6. Heating, Ventilating, } \\
\text { and Air Conditioning and } \\
\text { 12. Normative References }\end{array}$ & $\begin{array}{l}\text { This addendum changes Table } 6.8 .1 \mathrm{~F} \text { to add an additional requirement of } \\
\text { combustion efficiency to the current requirement of thermal efficiency for } \\
\text { boilers, which will increase minimum efficiency. The reference in Section } 12 \\
\text { has also been changed to reflect the change in the table. }\end{array}$ & $1 / 21 / 06$ & $1 / 26 / 06$ & $1 / 18 / 06$ & $4 / 10 / 06$ \\
\hline $90.1 \mathrm{u}$ & Informative Appendix G & $\begin{array}{l}\text { This addendum provides guidance for complying with the intent of the } \\
\text { baseline building design for HVAC systems } 5,6,7 \text {, and } 8 \text {, which shall be } \\
\text { modeled as floor-by-floor HVAC systems. }\end{array}$ & $1 / 21 / 06$ & $1 / 26 / 06$ & $1 / 18 / 06$ & $4 / 10 / 06$ \\
\hline $90.1 \mathrm{v}$ & $\begin{array}{l}\text { 6. Heating, Ventilating, } \\
\text { and Air Conditioning }\end{array}$ & $\begin{array}{l}\text { This addendum modifies the provisions of Section 6.4.3.8 to allow for } \\
\text { demand control ventilation. }\end{array}$ & $1 / 21 / 06$ & $1 / 26 / 06$ & $1 / 18 / 06$ & $5 / 10 / 06$ \\
\hline $90.1 \mathrm{x}$ & $\begin{array}{l}\text { 12. Normative References } \\
\text { and Informative } \\
\text { Appendix G }\end{array}$ & $\begin{array}{l}\text { This addendum updates the normative references in Section } 12 \text { and } \\
\text { Informative Appendix G for ATM- } 02 \text { to ATM- } 04 \text {. }\end{array}$ & $1 / 21 / 06$ & $1 / 26 / 06$ & $1 / 18 / 06$ & $4 / 10 / 06$ \\
\hline $90.1 \mathrm{y}$ & $\begin{array}{l}\text { 5. Envelope, } 12 \text {. } \\
\text { Normative References, } \\
\text { and } \\
\text { Informative Appendix G }\end{array}$ & $\begin{array}{l}\text { This addendum adds a reference and method of test for deriving SRI (ASTM } \\
\text { Test Method E, 1980) for high albedo roofs. The changes in the standard were } \\
\text { in both Section } 5 \text { and Informative Appendix G. }\end{array}$ & $6 / 24 / 06$ & $6 / 29 / 06$ & $6 / 18 / 06$ & $3 / 3 / 07$ \\
\hline 90.1 aа & 9. Lighting & This addendum modifies Section 9.1 to clarify some lighting requirements. & $6 / 24 / 06$ & $6 / 29 / 06$ & $6 / 18 / 06$ & $3 / 3 / 07$ \\
\hline $90.1 \mathrm{ab}$ & $\begin{array}{l}\text { 11. Energy Cost Budget } \\
\text { Method and Informative } \\
\text { Appendix G }\end{array}$ & $\begin{array}{l}\text { This addendum corrects the referenced section in Tables 11.3.1 and G3.1; } \\
\text { Heating, Ventilating, and Air Conditioning to Sections 9.1.3, 9.1.4, and 9.2. }\end{array}$ & $6 / 24 / 06$ & $6 / 29 / 06$ & $6 / 18 / 06$ & $3 / 3 / 07$ \\
\hline $90.1 \mathrm{ac}$ & $\begin{array}{l}\text { 3. Definitions and } \\
\text { 6. Heating, Ventilating, } \\
\text { and Air Conditioning }\end{array}$ & $\begin{array}{l}\text { This addendum modifies the fan power limitation requirements in Section } \\
6.5 .3 \text {. }\end{array}$ & $1 / 27 / 07$ & $3 / 2 / 07$ & $1 / 18 / 07$ & $3 / 27 / 07$ \\
\hline $90.1 \mathrm{ad}$ & 5. Building Envelope & $\begin{array}{l}\text { This addendum changes the exception to Section } 5.3 .1 .1 \text { to add a requirement } \\
\text { that the values for solar reflectance and thermal emittance be determined by a } \\
\text { laboratory accredited by a nationally recognized accreditation organization, } \\
\text { such as the Cool Roof Rating Council. }\end{array}$ & $2 / 5 / 05$ & $2 / 10 / 05$ & $2 / 3 / 05$ & $3 / 14 / 05$ \\
\hline $90.1 \mathrm{ae}$ & $\begin{array}{l}\text { 11. Energy Cost Budget } \\
\text { Method and Informative } \\
\text { Appendix G }\end{array}$ & $\begin{array}{l}\text { Clarifies that average lighting power density for each thermal block should be } \\
\text { modeled (originally listed as "Change to Section 9.2.1.1, "Space Control," in } \\
\text { Appendix F). }\end{array}$ & $1 / 27 / 07$ & $3 / 2 / 07$ & $1 / 18 / 07$ & $3 / 27 / 07$ \\
\hline
\end{tabular}




\begin{tabular}{|c|c|c|c|c|c|c|}
\hline $\begin{array}{c}\text { Addenda to } \\
90.1-2004\end{array}$ & Section(s) Affected & Description of Changes & $\begin{array}{l}\text { ASHRAE } \\
\text { Standards } \\
\text { Committee } \\
\text { Approval Date }\end{array}$ & $\begin{array}{c}\text { ASHRAE } \\
\text { Board of } \\
\text { Directors } \\
\text { Approval } \\
\text { Date }\end{array}$ & $\begin{array}{l}\text { IESNA } \\
\text { Approval } \\
\text { Date }\end{array}$ & $\begin{array}{l}\text { ANSI } \\
\text { Approval } \\
\text { Date }\end{array}$ \\
\hline 90.1ag & Informative Appendix G & $\begin{array}{l}\text { This addendum clarifies that only HVAC fans that provide outdoor air for } \\
\text { ventilation need to be modeled as running continuously. }\end{array}$ & $6 / 24 / 06$ & $6 / 29 / 06$ & $6 / 18 / 06$ & $3 / 3 / 07$ \\
\hline 90.1ah & $\begin{array}{l}\text { 11. Energy Cost Budget } \\
\text { Method }\end{array}$ & $\begin{array}{l}\text { This addendum modifies the requirements in Table } 11.3 .1 \text { for condenser heat } \\
\text { recovery. }\end{array}$ & $6 / 24 / 06$ & $6 / 29 / 06$ & $6 / 18 / 06$ & $3 / 3 / 07$ \\
\hline 90.1 ai & 9. Lighting & $\begin{array}{l}\text { This addendum modifies the interior lighting power requirements for retail } \\
\text { display lighting in Section 9.6.2. }\end{array}$ & $1 / 27 / 07$ & $3 / 2 / 07$ & $1 / 18 / 07$ & $3 / 27 / 07$ \\
\hline 90.1 aj & 5. Building Envelope & $\begin{array}{l}\text { This addendum modifies the exception to Section } 5.5 .3 .1 \text { by adding the } \\
\text { ASTM Test Method E 1980-Standard Practice for Calculating Solar } \\
\text { Reflectance Index (SRI) of Horizontal and Low Sloped Opaque Surfaces. }\end{array}$ & $6 / 24 / 06$ & $6 / 29 / 06$ & $6 / 18 / 06$ & $3 / 3 / 07$ \\
\hline $90.1 \mathrm{ak}$ & $\begin{array}{l}\text { Table } 6.2 .1 \mathrm{G} \text {, } \\
\text { Performance } \\
\text { Requirements for Heat } \\
\text { Rejection Equipment, and } \\
\text { Section 6.2.1 }\end{array}$ & $\begin{array}{l}\text { This addendum changes Table } 6.2 .1 \mathrm{G} \text { to add requirements for cooling towers } \\
\text { to be tested to CTI test procedures and to update the corresponding references } \\
\text { in Section 6.2.1. }\end{array}$ & $6 / 24 / 06$ & $6 / 29 / 06$ & $6 / 18 / 06$ & $3 / 3 / 07$ \\
\hline $90.1 \mathrm{al}$ & Normative Appendix A & $\begin{array}{l}\text { This addendum corrects the terminology used in Section A2.3 for metal } \\
\text { building roofs. }\end{array}$ & $6 / 24 / 06$ & $6 / 29 / 06$ & $6 / 18 / 06$ & $3 / 3 / 07$ \\
\hline $90.1 \mathrm{am}$ & $\begin{array}{l}\text { 11. Energy Cost Budget } \\
\text { Method and Informative } \\
\text { Appendix G }\end{array}$ & $\begin{array}{l}\text { This addendum modifies the VAV turndown requirements in Section } 11 \text { and } \\
\text { Informative Appendix G in accordance to the requirements in Section 6.5.2.1. }\end{array}$ & $6 / 24 / 06$ & $6 / 29 / 06$ & $6 / 18 / 06$ & $3 / 3 / 07$ \\
\hline 90.1 an & $\begin{array}{l}\text { 6. Heating, Ventilating, } \\
\text { and Air Conditioning }\end{array}$ & $\begin{array}{l}\text { This addendum modifies the equipment efficiency requirements for } \\
\text { commercial boilers in Table 6.8.1F. }\end{array}$ & $1 / 27 / 07$ & $3 / 2 / 07$ & $1 / 18 / 07$ & $3 / 27 / 07$ \\
\hline 90.1 ao & $\begin{array}{l}\text { 6. Heating, Ventilating, } \\
\text { and Air Conditioning }\end{array}$ & $\begin{array}{l}\text { This addendum adds a footnote for increasing unit heater efficiency } \\
\text { requirements (requiring intermittent ignition devices, power venting, or flue } \\
\text { dampers) to comply with federal law. }\end{array}$ & $1 / 27 / 07$ & $3 / 2 / 07$ & $1 / 18 / 07$ & $3 / 27 / 07$ \\
\hline 90.1ap & 9. Lighting & This addendum clarifies the intent of a "sales area" space in Table 9.6.1. & $1 / 27 / 07$ & $3 / 2 / 07$ & $1 / 18 / 07$ & $3 / 3 / 07$ \\
\hline $90.1 \mathrm{aq}$ & 12. Normative References & This addendum updates the references to CTI documents. & $1 / 27 / 07$ & $3 / 2 / 07$ & $1 / 18 / 07$ & $3 / 3 / 07$ \\
\hline $90.1 \mathrm{ar}$ & 6. Mechanical & $\begin{array}{l}\text { This addendum lowers the part-load fan power limitation from } 15 \mathrm{HP} \text { to } 10 \\
\mathrm{HP} \text { in Section 6.5.3.2.1. }\end{array}$ & $1 / 27 / 07$ & $3 / 2 / 07$ & $1 / 18 / 07$ & $3 / 3 / 07$ \\
\hline
\end{tabular}




\begin{tabular}{|c|c|c|c|c|c|c|}
\hline $\begin{array}{l}\text { Addenda to } \\
\text { 90.1-2004 }\end{array}$ & Section(s) Affected & Description of Changes & $\begin{array}{c}\text { ASHRAE } \\
\text { Standards } \\
\text { Committee } \\
\text { Approval Date }\end{array}$ & $\begin{array}{l}\text { ASHRAE } \\
\text { Board of } \\
\text { Directors } \\
\text { Approval } \\
\text { Date }\end{array}$ & $\begin{array}{l}\text { IESNA } \\
\text { Approval } \\
\text { Date }\end{array}$ & $\begin{array}{c}\text { ANSI } \\
\text { Approval } \\
\text { Date }\end{array}$ \\
\hline 90.1 as & 5. Building Envelope & $\begin{array}{l}\text { This addendum modifies the opaque assembly requirements in Tables } 5.5-1 \\
\text { through 5.5-8. }\end{array}$ & $5 / 18 / 07$ & $6 / 4 / 07$ & $6 / 4 / 07$ & $12 / 18 / 07$ \\
\hline 90.1 at & 5. Building Envelope & $\begin{array}{l}\text { This addendum modifies the fenestration requirements in Tables } 5.5-1 \\
\text { through 5.5-8. }\end{array}$ & $5 / 18 / 07$ & $6 / 4 / 07$ & $6 / 4 / 07$ & $12 / 18 / 07$ \\
\hline $90.1 \mathrm{av}$ & 5. Building Envelope & $\begin{array}{l}\text { This addendum adds an exception to Section 5.5.4.4.1 to allow credit for } \\
\text { overhangs composed of open louvers toward compliance with the maximum } \\
\text { SHGC requirements. }\end{array}$ & $1 / 27 / 07$ & $3 / 2 / 07$ & $1 / 18 / 07$ & $3 / 3 / 07$ \\
\hline
\end{tabular}




\subsection{Evaluation of Energy Efficiency Impacts of Addenda in Standard 90.1-2007}

After obtaining the complete listing of ASHRAE addenda (Table 3.1), each addendum was examined to provide a subjective evaluation of the impact of the addenda on overall building energy efficiency. Many of the addenda simply clarify the text of Standard 90.1 and have no impact on energy efficiency. Other addenda have significant positive or negative impacts on energy efficiency. The most common type of positive impact on energy efficiency occurs when a requirement is changed to a higher level of performance. The reverse change, from a higher level of performance to a lower level of performance, is less common. However, there are a number of addenda where exceptions are provided for various requirements and addition of an exception or expansion of an exception would be considered a negative impact on energy efficiency.

No attempt is made to quantify the impact on energy efficiency except to rank changes as major or minor. Quantification of the impact on energy efficiency is the focus of the second part of DOE's determination process. A later section in this document will address the possibility of quantifying the impact of each individual addendum.

Table 4.1 assesses the energy efficiency impact of each addendum. Addenda are ranked as "+" (having significant positive impact), "minor +" (minor positive impact), "0" (no impact), "-" (negative impact), or "minor -" (minor negative impact) on energy efficiency. A reason for the ranking is provided for each addendum as well. Two addenda are also listed as having "small but unquantifiable impact" because the assumed impact depends on DOE's interpretations of the existing language of Standard 90.12004. The rating provided for each addendum includes consideration of its impact on all compliance paths where the addendum has an impact 
Table 4.1. Summary of Differences between Standards 90.1-2004 and 90.1-2007, by Addenda

\begin{tabular}{|c|c|c|c|c|c|c|}
\hline No & $\begin{array}{l}\text { Addenda } \\
\text { to } 90.1- \\
2004 \\
\end{array}$ & Section Affected & Location in 90.1-2004 Edition & $\begin{array}{l}\text { Location in } \\
\text { 90.1-2007 } \\
\text { Edition } \\
\end{array}$ & Description of Changes & $\begin{array}{l}\text { Impact on Energy } \\
\text { Efficiency and } \\
\text { Reason }\end{array}$ \\
\hline 1 & $90.1-04 a$ & $\begin{array}{l}\text { Informative } \\
\text { Appendix G. } \\
\text { Performance } \\
\text { Rating Method }\end{array}$ & $\begin{array}{l}\text { Sections G2.1.4, G3.1, G3.6, } \\
\text { G3.8, G4.1, G4.2, G4.3, and } \\
\text { G4.5. }\end{array}$ & Same & $\begin{array}{l}\text { Clarifies window distribution, treatment of un-insulated } \\
\text { assemblies, increases size range for use of packaged } \\
\text { VAV systems, and provides more detail on hot water } \\
\text { system modeling. Also adds reference to ASHRAE } \\
\text { Standard } 140 .\end{array}$ & $\begin{array}{l}0 \text { (adds language to } \\
\text { informative appendix } \\
\text { only) }\end{array}$ \\
\hline 2 & $90.1-04 b$ & $\begin{array}{l}\text { 6. Heating, } \\
\text { Ventilating, and } \\
\text { Air Conditioning }\end{array}$ & Table 6.8.1D & Same & $\begin{array}{l}\text { Revision of requirements for single package vertical air } \\
\text { conditioners and heat pumps to address appropriate test } \\
\text { procedures and match Federal regulations. }\end{array}$ & $\begin{array}{l}0 \text { (brings standard into } \\
\text { alignment with } \\
\text { existing Federal } \\
\text { regulations) }\end{array}$ \\
\hline 3 & $90.1-04 c$ & $\begin{array}{l}\text { 5. Building } \\
\text { Envelope }\end{array}$ & Section 5.4.3.4 Vestibules & Same & $\begin{array}{l}\text { Clarification of vestibule requirements and bringing } \\
\text { those requirements in line with good building practices } \\
\text { in moderate and cold climates. Limits previous } 90.1 \text { - } \\
2004 \text { exception for building less than four stories above } \\
\text { grade to buildings in climate zones } 3 \text { and } 4 \text { less than } \\
10,000 \mathrm{ft}^{2} \text { in floor area and adds an exception for small } \\
\text { buildings (less than } 1,000 \mathrm{ft}^{2} \text { ) in climates zones } 5-8 \text {. }\end{array}$ & $\begin{array}{l}\text { Minor }+ \text { (limits } \\
\text { exception for building } \\
\text { height in mandatory } \\
\text { envelope } \\
\text { requirements) }\end{array}$ \\
\hline 4 & $90.1-04 d$ & $\begin{array}{l}\text { 12. Normative } \\
\text { References }\end{array}$ & 12. Normative References & Same & Updates ASTM and NFRC references & $\begin{array}{l}0 \text { (updates references } \\
\text { only) }\end{array}$ \\
\hline 5 & $90.1-04 \mathrm{e}$ & 9. Lighting & 9.1.4 Luminaire Wattage & Same & $\begin{array}{l}\text { Allows use of circuit breaker and permanently installed } \\
\text { current limiter wattage instead of a fixed } 30 \text { watts per } \\
\text { linear foot for line-voltage track and plug-in busway }\end{array}$ & $\begin{array}{l}0 \text { (no evidence it will } \\
\text { increase or decrease } \\
\text { energy usage) }\end{array}$ \\
\hline 6 & $90.1-04 f$ & $\begin{array}{l}\text { 6. Heating, } \\
\text { Ventilating, and } \\
\text { Air Conditioning }\end{array}$ & $\begin{array}{l}\text { Table 6.8.1A Electrically } \\
\text { Operated Unitary Air } \\
\text { Conditioners and Condensing } \\
\text { Units - Minimum Efficiency } \\
\text { Requirements, Table 6.8.1B } \\
\text { Electrically Operated Unitary } \\
\text { and Applied Heat Pumps - } \\
\text { Minimum Efficiency } \\
\text { Requirements }\end{array}$ & Same & $\begin{array}{l}\text { Implements results of US Appeals Court decision } \\
\text { reinstating SEER } 13 \text { requirements for residential-sized } \\
\text { (less than } 65,000 \mathrm{Btu} / \mathrm{hr} \text { ) air conditioners }\end{array}$ & $\begin{array}{l}0 \text { (brings standard into } \\
\text { alignment with } \\
\text { existing Federal } \\
\text { regulations) }\end{array}$ \\
\hline
\end{tabular}




\begin{tabular}{|c|c|c|c|c|c|c|}
\hline No & $\begin{array}{l}\text { Addenda } \\
\text { to 90.1- } \\
2004\end{array}$ & Section Affected & Location in 90.1-2004 Edition & $\begin{array}{l}\text { Location in } \\
\text { 90.1-2007 } \\
\text { Edition }\end{array}$ & Description of Changes & $\begin{array}{l}\text { Impact on Energy } \\
\text { Efficiency and } \\
\text { Reason }\end{array}$ \\
\hline 7 & $90.1-04 \mathrm{~g}$ & $\begin{array}{l}\text { 6. Heating, } \\
\text { Ventilating, and } \\
\text { Air Conditioning }\end{array}$ & $\begin{array}{l}\text { Table 6.8.1A Electrically } \\
\text { Operated Unitary Air } \\
\text { Conditioners and Condensing } \\
\text { Units - Minimum Efficiency } \\
\text { Requirements, Table 6.8.1B } \\
\text { Electrically Operated Unitary } \\
\text { and Applied Heat Pumps - } \\
\text { Minimum Efficiency } \\
\text { Requirements }\end{array}$ & Same & $\begin{array}{l}\text { Implements results of DOE equipment rulemaking for } \\
\text { air conditioners larger than } 65,000 \mathrm{Btu} / \mathrm{hr}\end{array}$ & $\begin{array}{l}0 \text { (brings standard into } \\
\text { alignment with } \\
\text { existing Federal } \\
\text { regulations) }\end{array}$ \\
\hline 8 & $90.1-04 \mathrm{~h}$ & $\begin{array}{l}\text { 6. Heating, } \\
\text { Ventilating, and } \\
\text { Air Conditioning }\end{array}$ & $\begin{array}{l}\text { Section 6.4.3.1.2 Dead Band and } \\
\text { Section 6.4.3.6 Humidification } \\
\text { and Dehumidification }\end{array}$ & Same & $\begin{array}{l}\text { Removes dead band exception for data processing areas } \\
\text { and removes exception to ban on simultaneous } \\
\text { humidification and dehumidification for computer } \\
\text { rooms }\end{array}$ & $\begin{array}{l}\text { Minor }+ \text { (removes } \\
\text { exceptions) }\end{array}$ \\
\hline 9 & $90.1-04 \mathrm{i}$ & 9. Lighting & $\begin{array}{l}\text { Section 9.1.4 Luminaire } \\
\text { Wattage }\end{array}$ & Same & $\begin{array}{l}\text { Adds option to use maximum labeled wattage of } \\
\text { luminaire for luminaires with permanently installed or } \\
\text { remote ballast or transformers }\end{array}$ & $\begin{array}{l}0 \text { (adds nominally } \\
\text { equal energy option) }\end{array}$ \\
\hline 10 & $90.1-04 j$ & 9. Lighting & $\begin{array}{l}\text { Section 9.4.1.3 Exterior Lighting } \\
\text { Control }\end{array}$ & Same & $\begin{array}{l}\text { Allows use of a combination of a photosensor and a time } \\
\text { switch in place of an astronomical time switch for } \\
\text { controlling exterior lighting }\end{array}$ & $\begin{array}{l}0 \text { (adds nominally } \\
\text { equal energy option) }\end{array}$ \\
\hline 11 & $90.1-04 \mathrm{k}$ & $\begin{array}{l}\text { Normative } \\
\text { Appendix A. Rated } \\
\text { R-Value of } \\
\text { Insulation and } \\
\text { Assembly U- } \\
\text { Factor, C-Factor, } \\
\text { and F-Factor } \\
\text { Determinations }\end{array}$ & $\begin{array}{l}\text { Table A2.3 Assembly U-Factors } \\
\text { for Metal Building Roofs }\end{array}$ & Same & Adds U-factors for R-19 insulation in screw down roofs & 0 (adds reference data) \\
\hline 12 & 90.1-041 & $\begin{array}{l}\text { 12. Normative } \\
\text { References }\end{array}$ & 12. Normative References & Same & Updates reference to ASHRAE Standard 140 & $\begin{array}{l}0 \text { (updates references } \\
\text { only) }\end{array}$ \\
\hline 13 & $90.1-04 \mathrm{~m}$ & 9. Lighting & 9.2.2.3 Interior Lighting Power & Same & $\begin{array}{l}\text { Adds an exception for furniture mounted task lighting } \\
\text { controlled by automatic shutoff }\end{array}$ & $\begin{array}{l}\text { Minor but } \\
\text { unquantifiable }- \text { see } \\
\text { detailed discussion }\end{array}$ \\
\hline 14 & $90.1-04 n$ & 5. Envelope & $\begin{array}{l}\text { 5.5.4.4 Fenestration Solar Heat } \\
\text { Gain Coefficient (SHGC) }\end{array}$ & Same & $\begin{array}{l}\text { Adds instructions for dealing with SHGC credit for } \\
\text { partially opaque permanent projections such as framing } \\
\text { with glass or perforated metal }\end{array}$ & $\begin{array}{l}0 \text { (adds nominally } \\
\text { equal energy option) }\end{array}$ \\
\hline 15 & $90.1-04 \mathrm{o}$ & $\begin{array}{l}\text { Normative } \\
\text { Appendix D. } \\
\text { Climatic Data }\end{array}$ & $\begin{array}{l}\text { Table D-3 International } \\
\text { Climatic Data }\end{array}$ & Same & $\begin{array}{l}\text { Adds additional climatic data for China and Taiwan and } \\
\text { corrects errors for climatic data for Malaysia and } \\
\text { Mexico }\end{array}$ & $\begin{array}{l}0 \text { (adds or corrects } \\
\text { reference data) }\end{array}$ \\
\hline
\end{tabular}




\begin{tabular}{|c|c|c|c|c|c|c|}
\hline No & $\begin{array}{l}\text { Addenda } \\
\text { to } 90.1- \\
2004 \\
\end{array}$ & Section Affected & Location in 90.1-2004 Edition & $\begin{array}{l}\text { Location in } \\
\text { 90.1-2007 } \\
\text { Edition }\end{array}$ & Description of Changes & $\begin{array}{l}\text { Impact on Energy } \\
\text { Efficiency and } \\
\text { Reason }\end{array}$ \\
\hline 16 & $90.1-04 p$ & 9. Lighting & 9.2.2.3 Interior Lighting Power & Same & $\begin{array}{l}\text { Modifies text related to exception for lighting for } \\
\text { visually impaired to clarify that any special needs } \\
\text { lighting for visual impairment and other medical and } \\
\text { age-related issues is exempt }\end{array}$ & $\begin{array}{l}\text { Minor -, but } \\
\text { unquantifiable }- \text { see } \\
\text { detailed discussion }\end{array}$ \\
\hline 17 & $90.1-04 q$ & $\begin{array}{l}\text { 6. Heating, } \\
\text { Ventilating, and } \\
\text { Air Conditioning }\end{array}$ & $\begin{array}{l}\text { 6.4.3.2 Set Point Overlap } \\
\text { Restriction (a) Off-Hour } \\
\text { Controls) - Should be Section } \\
\text { 6.4.3.3 but printed version has } \\
\text { typographical error }\end{array}$ & $\begin{array}{l}\text { Same } \\
(6.4 .3 .3)\end{array}$ & $\begin{array}{l}\text { Removes exception of off-hour control requirements for } \\
\text { hotel/motel guest rooms }\end{array}$ & $\begin{array}{l}\text { Minor }+ \text { (applies off- } \\
\text { hour control } \\
\text { requirements for more } \\
\text { building types) }\end{array}$ \\
\hline 18 & $90.1-04 \mathrm{r}$ & $\begin{array}{l}\text { 12. Normative } \\
\text { References }\end{array}$ & 12. Normative References & Same & $\begin{array}{l}\text { Updates reference to ARI Standard 340/360 from } 2000 \\
\text { to } 2004 \text { edition }\end{array}$ & $\begin{array}{l}0 \text { (updates references } \\
\text { only) }\end{array}$ \\
\hline 19 & $90.1-04 \mathrm{~s}$ & $\begin{array}{l}\text { 6. Heating, } \\
\text { Ventilating, and } \\
\text { Air Conditioning } \\
\text { and } 12 . \text { Normative } \\
\text { References }\end{array}$ & $\begin{array}{l}\text { 6.4.3.8 Ventilation Controls for } \\
\text { High-Occupancy Areas; } 6.5 .1 \\
\text { Economizers; 6.5.2.1 Zone } \\
\text { Controls; and 6.5.2.3 } \\
\text { Dehumidification and 12. } \\
\text { Normative References }\end{array}$ & Same & $\begin{array}{l}\text { 1. Removes reference to ASHRAE Standard } 62 \\
\text { compliance for ventilation controls for high-occupancy } \\
\text { areas } \\
\text { 2. Replaces "gas phase air cleaning" with "non- } \\
\text { particulate air treatment" in economizer exceptions } \\
\text { 3. Removes reference to ASHRAE Standard } 62 \text { in zone } \\
\text { control exceptions } \\
\text { 4. Points to Section } 6.2 \text { of Standard } 62.1 \text { instead of } \\
\text { Section } 6.1 .3 \text { for dehumidification exception } \\
\text { 5. Updates Standard } 62-1999 \text { reference to Standard } \\
\text { 62.1-2004. }\end{array}$ & $\begin{array}{l}0 \text { (editorial) } \\
\text { (Potentially }+ \text { if switch } \\
\text { from 62-1999 to 62.1- } \\
2004 \text { is included. See } \\
\text { detailed discussion) }\end{array}$ \\
\hline 20 & $90.1-04 t$ & $\begin{array}{l}\text { 6. Heating, } \\
\text { Ventilating, and } \\
\text { Air Conditioning }\end{array}$ & Table $6.8 .1 \mathrm{~F}$ & Same & $\begin{array}{l}\text { Adds additional combustion efficiency requirement to } \\
\text { thermal efficiency requirement for boilers and replaces } \\
\text { H.I. Heating Boiler Standard with new DOE } 10 \text { CFR } \\
\text { Part } 431 \text { test procedures }\end{array}$ & $\begin{array}{l}0 \text { (brings standard into } \\
\text { alignment with exising } \\
\text { federal standards for } \\
\text { boiler combustion } \\
\text { efficiency) }\end{array}$ \\
\hline 21 & $90.1-04 u$ & $\begin{array}{l}\text { Informative } \\
\text { Appendix G }\end{array}$ & $\begin{array}{l}\text { G3.1.1 Baseline HVAC System } \\
\text { Type and Description }\end{array}$ & Same & $\begin{array}{l}\text { Requires that systems } 1-4 \text { shall be modeled with a } \\
\text { system for each thermal block and systems } 5-8 \text { shall be } \\
\text { modeled with a separate system for each floor. }\end{array}$ & $\begin{array}{l}0 \text { (updates informative } \\
\text { appendix only only) }\end{array}$ \\
\hline 22 & $90.1-04 v$ & $\begin{array}{l}\text { 6. Heating, } \\
\text { Ventilating, and } \\
\text { Air Conditioning } \\
\text { and 3. Definitions, } \\
\text { Abbreviations, and } \\
\text { Acronyms }\end{array}$ & $\begin{array}{l}\text { 6.4.3.8 Ventilation Controls for } \\
\text { High-Occupancy Areas and } 3.2 \\
\text { Definitions }\end{array}$ & Same & $\begin{array}{l}\text { Adds new definition for demand control ventilation and } \\
\text { requires demand control ventilation for spaces with } \\
\text { high-occupancy. High occupancy is now defined as } \\
\text { spaces with ventilation for more than } 40 \text { people per } 1000 \\
\mathrm{ft}^{2}\left(\text { as opposed to } 100 \text { people per } 1000 \mathrm{ft}^{2}\right) \text {. Spaces } \\
\text { below } 500 \mathrm{ft}^{2} \text { and system with a design outdoor air flow } \\
\text { less than } 1,200 \mathrm{cfm} \text { are exempt. }\end{array}$ & $\begin{array}{l}\text { Major }+(\text { applies } \\
\text { demand control } \\
\text { ventilation to more } \\
\text { spaces) }\end{array}$ \\
\hline
\end{tabular}




\begin{tabular}{|c|c|c|c|c|c|c|}
\hline No & $\begin{array}{l}\text { Addenda } \\
\text { to } 90.1- \\
2004 \\
\end{array}$ & Section Affected & Location in 90.1-2004 Edition & $\begin{array}{l}\text { Location in } \\
\text { 90.1-2007 } \\
\text { Edition }\end{array}$ & Description of Changes & $\begin{array}{l}\text { Impact on Energy } \\
\text { Efficiency and } \\
\text { Reason }\end{array}$ \\
\hline 23 & $90.1-04 x$ & $\begin{array}{l}\text { Informative } \\
\text { Appendix G } \\
\text { Performance } \\
\text { Rating Method and } \\
\text { 12. Normative } \\
\text { References }\end{array}$ & $\begin{array}{l}\text { Table G3.15 Building Envelope } \\
\text { Exception C and 12. Normative } \\
\text { References }\end{array}$ & Same & $\begin{array}{l}\text { Updates reference to ASTM C1549 and add ASTM } \\
\text { C1549 as an allowable reference for roof reflectance } \\
\text { measurements. Eliminates references to ASTM C } 835 \\
\text { and ASTM E1175 }\end{array}$ & $\begin{array}{l}0 \text { (updates informative } \\
\text { appendix only) }\end{array}$ \\
\hline 24 & $90.1-04 y$ & $\begin{array}{l}\text { 5. Building } \\
\text { Envelope and } 12 . \\
\text { Normative } \\
\text { References and } \\
\text { Informative } \\
\text { Appendix G }\end{array}$ & $\begin{array}{l}\text { 5.5.3.1 Roof Insulation and } 12 . \\
\text { Normative References }\end{array}$ & Same & $\begin{array}{l}\text { Adds reference and method of test for deriving Solar } \\
\text { Reflectivity Index (ASTM E1980) as an option to solar } \\
\text { reflectance and solar transmittance }\end{array}$ & $\begin{array}{l}0 \text { (provides an } \\
\text { additional alternative) }\end{array}$ \\
\hline 25 & 90.1-04aa & $\begin{array}{l}\text { 9. Lighting and } 3 . \\
\text { Definitions, } \\
\text { Abbreviations and } \\
\text { Acronyms and } \\
\text { Informative } \\
\text { Appendix G } \\
\text { Performance } \\
\text { Rating Method }\end{array}$ & $\begin{array}{l}\text { 3.2 Definitions and } 9.1 .3 \\
\text { Installed Interior Lighting Power } \\
\text { and Table G3.1 Item } 6 \text { Lighting } \\
\text { and Table G3.1 Item } 9 \text { Thermal } \\
\text { Blocks }\end{array}$ & Same & $\begin{array}{l}\text { Adds definitions for astronomical time switch, efficacy } \\
\text { of a lamp, eye adaptation, high-frequency electronic } \\
\text { ballast, photosensor, and task lighting and also replaces } \\
\text { undefined terms "current regulator" with "transformer" } \\
\text { and "living units" with "dwelling units" }\end{array}$ & $\begin{array}{l}0 \text { (editorial changes } \\
\text { only) }\end{array}$ \\
\hline 26 & $90.1-04 a b$ & $\begin{array}{l}11 \text { Energy Cost } \\
\text { Budget Method } \\
\text { and Informative } \\
\text { Appendix G } \\
\text { Performance } \\
\text { Rating Method }\end{array}$ & $\begin{array}{l}\text { Table 11.3.1 Modeling } \\
\text { Requirements for Calculating } \\
\text { Design Energy Cost and Energy } \\
\text { Cost Budget and Table G3.1 } \\
\text { Modeling Requirements for } \\
\text { Calculating Proposed and } \\
\text { Baseline Building Performance }\end{array}$ & Same & $\begin{array}{l}\text { Changes references to lighting sections and subsections } \\
\text { to match current standard }\end{array}$ & $\begin{array}{l}0 \text { (editorial changes } \\
\text { only) }\end{array}$ \\
\hline
\end{tabular}




\begin{tabular}{|c|c|c|c|c|c|c|}
\hline No & $\begin{array}{l}\text { Addenda } \\
\text { to } 90.1- \\
2004 \\
\end{array}$ & Section Affected & Location in 90.1-2004 Edition & $\begin{array}{l}\text { Location in } \\
\text { 90.1-2007 } \\
\text { Edition }\end{array}$ & Description of Changes & $\begin{array}{l}\text { Impact on Energy } \\
\text { Efficiency and } \\
\text { Reason }\end{array}$ \\
\hline 27 & $90.1-04 \mathrm{ac}$ & $\begin{array}{l}\text { 6. Heating, } \\
\text { Ventilating, and } \\
\text { Air Conditioning } \\
\text { and 3. Definitions, } \\
\text { Abbreviations, and } \\
\text { Acronyms }\end{array}$ & $\begin{array}{l}\text { 6.5.3 Air System Design and } \\
\text { Control and } \\
\text { 3.2 Definitions }\end{array}$ & Same & $\begin{array}{l}\text { Strengthens stringency in fan power limitations for } \\
\text { simple systems with an easy-to-use format/structure. } \\
\text { Expands application coverage to properly address } \\
\text { complex exhaust fan systems associated with hospitals } \\
\text { and laboratories. Improves compliance consistency by } \\
\text { changing the fan power limitation structure based on a } \\
\text { continuous curve and eliminates the nominal motor hp } \\
\text { steps. } \\
\text { Adds definitions for fan brake horsepower, fan system } \\
\text { design conditions, fan system bhp, fan system motor } \\
\text { nameplate hp, and nameplate horsepower. }\end{array}$ & $\begin{array}{l}\text { Major }+(\text { expansion of } \\
\text { application coverage } \\
\text { and stringency for } \\
\text { simple systems })\end{array}$ \\
\hline 28 & $90.1-04 \mathrm{ad}$ & $\begin{array}{l}\text { 5. Building } \\
\text { Envelope and } 12 . \\
\text { Normative } \\
\text { References }\end{array}$ & 5.5.3.1 Roof Insulation & Same & $\begin{array}{l}\text { Provides recognition for the Cool Roof Rating Council } \\
\text { as a national accreditation organization for solar } \\
\text { reflectance and thermal emittance through their Cool } \\
\text { Roof Rating Council Product Rating Program, } \\
\text { eliminates references to ASTM C } 835 \text { and ASTM E1175, } \\
\text { adds reference to ASTM C1549 }\end{array}$ & $\begin{array}{l}0 \text { (reference changes } \\
\text { and requirement for } \\
\text { use of data from } \\
\text { accredited } \\
\text { organization) }\end{array}$ \\
\hline 29 & $90.1-04 \mathrm{ae}$ & $\begin{array}{l}\text { 11. Energy Cost } \\
\text { Budget Method } \\
\text { and Informative } \\
\text { Appendix G }\end{array}$ & & Same & $\begin{array}{l}\text { Clarifies that average lighting power density for each } \\
\text { thermal block should be modeled }\end{array}$ & $\begin{array}{l}0 \text { (clarification of } \\
\text { tradeoff and } \\
\text { informative only) }\end{array}$ \\
\hline 30 & 90.1-04ag & $\begin{array}{l}\text { Informative } \\
\text { Appendix G } \\
\text { Performance } \\
\text { Rating Method }\end{array}$ & $\begin{array}{l}\text { Table G3.1 Modeling } \\
\text { Requirements for Calculating } \\
\text { Proposed and Baseline Building } \\
\text { Performance }\end{array}$ & Same & $\begin{array}{l}\text { Clarifies that only HVAC fans that provide outdoor air } \\
\text { for ventilation need to be modeled as running } \\
\text { continuously }\end{array}$ & 0 (informative only) \\
\hline 31 & 90.1-04ah & $\begin{array}{l}11 \text { Energy Cost } \\
\text { Budget Method }\end{array}$ & $\begin{array}{l}\text { Table } 11.3 .1 \text { Modeling } \\
\text { Requirements for Calculating } \\
\text { Design Energy Cost and Energy } \\
\text { Cost Budget }\end{array}$ & Same & $\begin{array}{l}\text { Clarifies what to assume in budget building model is } \\
\text { condenser heat recovery is required by Section } 6.5 .2\end{array}$ & $\begin{array}{l}0 \text { (clarification of } \\
\text { tradeoff only) }\end{array}$ \\
\hline 32 & 90.1-04ai & 9. Lighting & 9.6 .3 & Same & $\begin{array}{l}\text { Revises additional lighting power allowance for retail } \\
\text { display lighting }\end{array}$ & $\begin{array}{l}\text { Minor }+ \text { (the primary } \\
\text { category power level } \\
\text { has been reduced } \\
\text { which will tend to } \\
\text { decrease energy use) }\end{array}$ \\
\hline 33 & 90.1-04aj & $\begin{array}{l}\text { 5. Building } \\
\text { Envelope and } 12 . \\
\text { Normative } \\
\text { References }\end{array}$ & $\begin{array}{l}\text { 5.5.3.1 Roof Insulation and } 12 . \\
\text { Normative References }\end{array}$ & Same & $\begin{array}{l}\text { Replaces roof U-multiplier table with prescriptive roof } \\
\text { U-factors and R-values. Also allows use of ASTM } \\
\text { E1980 for solar reflective index and adds requirements } \\
\text { when that standard is used. }\end{array}$ & $\begin{array}{l}0 \text { (mainly editorial } \\
\text { changes to an option) }\end{array}$ \\
\hline
\end{tabular}




\begin{tabular}{|c|c|c|c|c|c|c|}
\hline No & $\begin{array}{l}\text { Addenda } \\
\text { to } 90.1- \\
2004\end{array}$ & Section Affected & Location in 90.1-2004 Edition & $\begin{array}{l}\text { Location in } \\
\text { 90.1-2007 } \\
\text { Edition }\end{array}$ & Description of Changes & $\begin{array}{l}\text { Impact on Energy } \\
\text { Efficiency and } \\
\text { Reason }\end{array}$ \\
\hline 34 & 90.1-04ak & $\begin{array}{l}\text { 6. Heating, } \\
\text { Ventilating, and } \\
\text { Air Conditioning }\end{array}$ & $\begin{array}{l}\text { Table 6.8.1G Performance } \\
\text { Requirements for Heat Rejection } \\
\text { Equipment }\end{array}$ & Same & $\begin{array}{l}\text { Adds a third-party performance certification testing } \\
\text { program to heat rejection equipment requirements }\end{array}$ & $\begin{array}{l}\text { Minor }+ \text { (additional } \\
\text { certification) }\end{array}$ \\
\hline 35 & $90.1-04 \mathrm{al}$ & $\begin{array}{l}\text { Normative } \\
\text { Appendix A. Rated } \\
\text { R-Value of } \\
\text { Insulation and } \\
\text { Assembly U- } \\
\text { Factor, C-Factor, } \\
\text { and F-Factor } \\
\text { Determinations }\end{array}$ & $\begin{array}{l}\text { A2.3 Metal Building Roofs and } \\
\text { Table A2.3 Assembly U-Factors } \\
\text { for Metal Building Roofs }\end{array}$ & Same & $\begin{array}{l}\text { Changes "metal spanning members" to "metal roof } \\
\text { panels" in definition of metal building roofs, includes } \\
\text { mention of thermal spacer blocks for standing seam } \\
\text { roofs in Table A2.3 and changes description of "screw } \\
\text { down roofs" to "Thru-fastened roofs without thermal } \\
\text { spacer blocks" }\end{array}$ & 0 (editorial) \\
\hline 36 & 90.1-04am & $\begin{array}{l}\text { 11. Energy Cost } \\
\text { Budget Method } \\
\text { and Informative } \\
\text { Appendix G } \\
\text { Performance } \\
\text { Rating Method }\end{array}$ & $\begin{array}{l}\text { Table 11.3.2A Budget System } \\
\text { Descriptions and G3.1.3.13 } \\
\text { VAV Minimum Flow Setpoints } \\
\text { (Systems } 5 \text { and 7) }\end{array}$ & Same & $\begin{array}{l}\text { Changes the minimum flow setpoints of VAV systems } \\
\text { to } 0.4 \mathrm{cfm} / \mathrm{ft}^{2} \text { of floor area OR the minimum ventilation } \\
\text { rate, whichever is larger. }\end{array}$ & $\begin{array}{l}0 \text { (clarification of } \\
\text { tradeoff method and } \\
\text { informative method) }\end{array}$ \\
\hline 37 & $90.1-04 a n$ & $\begin{array}{l}\text { 6. Heating, } \\
\text { Ventilating, and } \\
\text { Air Conditioning }\end{array}$ & $\begin{array}{l}\text { Table 6.8.1F Gas and Oil Fired } \\
\text { Boilers, Minimum Efficiency } \\
\text { Requirements }\end{array}$ & Same & $\begin{array}{l}\text { Raises efficiency requirements for boilers in } 2009 \text { and } \\
\text { 2019. Adds efficiency requirement for lower capacity } \\
\text { category for oil-fired (residual) boilers. In addition, a } \\
\text { new product class is created for gas natural draft steam } \\
\text { boilers in order to permit a more gradual transition to the } \\
\text { proposed new standard level for this class. }\end{array}$ & $\begin{array}{l}\text { Major + (increases } \\
\text { efficiency for most } \\
\text { boilers in future) }\end{array}$ \\
\hline 38 & $90.1-04$ ao & $\begin{array}{l}\text { 6. Heating, } \\
\text { Ventilating, and } \\
\text { Air Conditioning }\end{array}$ & $\begin{array}{l}\text { Table 6.8.1E Warm Air Furnaces } \\
\text { and Combination Warm Air } \\
\text { Furnaces/Air-Conditioning } \\
\text { Units, Warm Air Duct Furnaces } \\
\text { and Unit Heaters }\end{array}$ & Same & $\begin{array}{l}\text { Adds requirement for intermittent ignition device as } \\
\text { required by the Energy Policy Act of 2005, Section } 135 \text {. }\end{array}$ & $\begin{array}{l}0 \text { (adds existing } \\
\text { Federal regulatory } \\
\text { requirement) }\end{array}$ \\
\hline 39 & 90.1-04ap & 9. Lighting & $\begin{array}{l}\text { Table 9.6.1 Lighting Power } \\
\text { Densities Using the Space-by- } \\
\text { Space Method }\end{array}$ & Same & $\begin{array}{l}\text { Clarifies intent of "sales area" space type and the } \\
\text { application of the retail additional lighting power } \\
\text { allowance }\end{array}$ & 0 (clarification only) \\
\hline 40 & $90.1-04 \mathrm{aq}$ & $\begin{array}{l}\text { 12. Normative } \\
\text { References }\end{array}$ & 12. Normative References & Same & Updates references for CTI ATC-105 and STD-201 & 0 (editorial only) \\
\hline 41 & $90.1-04 \mathrm{ar}$ & $\begin{array}{l}\text { 6. Heating, } \\
\text { Ventilating, and } \\
\text { Air Conditioning }\end{array}$ & $\begin{array}{l}\text { 6.5.3.2.1 Part-Load Fan Power } \\
\text { Limitation }\end{array}$ & Same & $\begin{array}{l}\text { Changes the part-load fan power limitation from } 15 \mathrm{hp} \\
\text { to } 10 \mathrm{hp}\end{array}$ & $\begin{array}{l}\text { Minor }+ \text { (applies } \\
\text { requirements to more } \\
\text { VAV fans) }\end{array}$ \\
\hline 42 & $90.1-04$ as & $\begin{array}{l}\text { 5. Building } \\
\text { Envelope }\end{array}$ & & Same & $\begin{array}{l}\text { Updates building envelope criteria for opaque } \\
\text { assemblies }\end{array}$ & $\begin{array}{l}\text { Major }+ \text { (some } \\
\text { increase in stringency) }\end{array}$ \\
\hline 43 & 90.1-04at & $\begin{array}{l}\text { 5. Building } \\
\text { Envelope }\end{array}$ & & & Update building envelope criteria for fenestration & $\begin{array}{l}\text { Major }+ \text { (some } \\
\text { increase in stringency) }\end{array}$ \\
\hline
\end{tabular}




\begin{tabular}{llllll}
\hline No & $\begin{array}{l}\text { Addenda } \\
\text { to 90.1- } \\
\mathbf{2 0 0 4}\end{array}$ & Section Affected & Location in 90.1-2004 Edition & $\begin{array}{l}\text { Location in } \\
\text { 90.1-2007 } \\
\text { Edition }\end{array}$ & $\begin{array}{l}\text { Description of Changes } \\
\text { Efficiency and } \\
\text { Reason }\end{array}$ \\
\hline 44 & $90.1-04 a \mathrm{av}$ & $\begin{array}{l}\text { 5. Building } \\
\text { Envelope }\end{array}$ & $\begin{array}{l}\text { 5.5.4.4 Fenestration Solar Heat } \\
\text { Gain Coefficient (SHGC) }\end{array}$ & $\begin{array}{l}\text { Same } \\
\text { Minor - (potential for } \\
\text { some additional } \\
\text { cooling load) }\end{array}$ \\
\hline
\end{tabular}


Table 4.2 shows the overall summary of the impacts of addenda.

Table 4.2. Overall Summary of Addenda Impact Overall Impact of Addenda

\begin{tabular}{|c|c|c|c|c|c|c|}
\hline Major Negative & Minor Negative & Neutral & Small but not quantifiable & Minor Positive & Major Positive & Total \\
\hline 0 & $2(\mathrm{p}, \mathrm{av})$ & 30 & $1(\mathrm{~m})$ & $\begin{array}{l}6(\mathrm{c}, \mathrm{h}, \mathrm{q}, \mathrm{ai}, \\
\mathrm{ak}, \mathrm{ar},)\end{array}$ & $\begin{array}{l}5(\mathrm{v}, \mathrm{ac}, \text { an, as, } \\
\text { at) }\end{array}$ & 44 \\
\hline \multicolumn{6}{|c|}{ Addenda with potential negative impacts for some buildings or spaces } & \\
\hline 0 & $2(\mathrm{p}, \mathrm{av})$ & 0 & $1(\mathrm{~m})$ & & 2 (as, at) & 5 \\
\hline
\end{tabular}

Table 4.3 shows the results of the textual analysis by section.

Table 4.3. Results of Textual Analysis by Section of Standard 90.1

\begin{tabular}{|c|c|c|c|c|c|}
\hline Section of Standard & $\begin{array}{l}\text { Number of } \\
\text { Changes Made to } \\
\text { Section }\end{array}$ & $\begin{array}{l}\text { Number of Positive } \\
\text { (Energy Saving) } \\
\text { Changes }\end{array}$ & $\begin{array}{l}\text { Number of } \\
\text { Unquantifiable } \\
\text { Changes }\end{array}$ & $\begin{array}{l}\text { Number of } \\
\text { Neutral (No } \\
\text { Energy Saving) } \\
\text { Changes } \\
\end{array}$ & $\begin{array}{l}\text { Number of } \\
\text { Negative (Energy } \\
\text { Increasing) } \\
\text { Changes } \\
\end{array}$ \\
\hline $\begin{array}{l}\text { Title, Purpose, and } \\
\text { Scope }\end{array}$ & 0 & 0 & 0 & 0 & 0 \\
\hline Definitions* & 0 & 0 & 0 & 0 & 0 \\
\hline $\begin{array}{l}\text { Administration and } \\
\text { Enforcement }\end{array}$ & 0 & 0 & 0 & 0 & 0 \\
\hline $\begin{array}{l}\text { Envelope and } \\
\text { Normative Appendices }\end{array}$ & 11 & 3 & 0 & 7 & 1 \\
\hline $\begin{array}{l}\text { HVAC Equipment and } \\
\text { Systems }\end{array}$ & 13 & 6 & 0 & 7 & 0 \\
\hline Service Water Heating & 0 & 0 & 0 & 0 & 0 \\
\hline Power & 0 & 0 & 0 & 0 & 0 \\
\hline Lighting & 9 & 2 & 1 & 5 & 1 \\
\hline $\begin{array}{l}\text { Energy Cost Budget } \\
\text { and Appendix G } \\
\text { Performance Rating } \\
\text { Method }\end{array}$ & 7 & 0 & 0 & 7 & 0 \\
\hline $\begin{array}{l}\text { Normative and } \\
\text { Informative } \\
\text { References }\end{array}$ & 4 & 0 & 0 & 4 & 0 \\
\hline Overall & 44 & 11 & 1 & 30 & 2 \\
\hline
\end{tabular}

Overall, the impacts of the positive changes outweigh the negative changes on a simple count basis. 



\subsection{Detailed Discussion of Impacts of Addenda on Various Sections of Standard 90.1-2007}

Standard 90.1-2007 contains 12 normative sections and 4 normative appendices that are considered part of the standard. Standard 90.1-2007 also contains 3 informative appendices that provide additional information relevant to use of the Standard, but that are not considered part of Standard 90.1-2007. DOE's evaluation of Standard 90.1-2007 focuses on the normative sections and appendices of the standard. This section of the qualitative analysis looks at each normative section and its associated appendices to identify the changes associated with each section and to assess the impact of those changes on various compliance paths allowed for that section.

Sections 5-9 are the heart of the technical requirements of Standard 90.1-2007. For Sections 5-9, Standard 90.1-2007 offers multiple compliance paths. Each section has mandatory requirements that must be met for all buildings. Each section may also have one or more sets of prescriptive requirements that must be met for all buildings unless a tradeoff option is used. Sections 5 and 6 have specific tradeoff options for use within these sections. Section 6 also has a simple system approach that combines mandatory and prescriptive requirements for certain buildings. Section 11 also provides an overall whole building tradeoff for Standard 90.1-2007 based on equal energy cost between a baseline building and the proposed design.

\subsection{Changes to Section 1, Purpose}

No changes were made to Section 1, Purpose, during the creation of Standard 90.1-2007.

\subsection{Changes to Section 2, Scope}

No changes were made to Section 2, Scope, during the creation of Standard 90.1-2007.

\subsection{Changes to Section 3, Definitions, Abbreviations, and Acronyms}

There were a number of updates to definitions in addenda to Standard 90.1-2004 that were included in Standard 90.1-2007. These definitions, and their impact on the stringency of the standard, are discussed in conjunction with the appropriate technical section (5-11) of Standard 90.1-2007, below.

\subsection{Changes to Section 4, Administration and Enforcement}

No changes were made to Section 4, Administration and Enforcement, during the creation of Standard 90.1.2007.

\subsection{Changes to Section 5, Building Envelope and Normative Appendices A-D}

The building envelope section has mandatory requirements applicable to all compliance paths and contains two compliance paths: prescriptive and envelope tradeoff. In addition, the prescriptive 
requirements of the building envelope section form the baseline envelope requirements for the whole building tradeoff method in Section 11, Energy Cost Budget Method.

Addendum c modifies the definition of building entrance to include vestibules and makes a series of changes to the vestibule requirement that use the revised definition. The addendum also changes the actual vestibule requirement by modifying the exceptions to requirement. The modifications include elimination of the blanket exemption for buildings less than four stories in grade and replacement of that exemption with two more specific exemptions - one exemption for buildings less than four stories and less than 10,000 $\mathrm{ft}^{2}$ in zones 3 and 4 and another exemption for buildings less than 1,000 $\mathrm{ft}^{2}$ in zones 5, 6 , 7 , and 8 . The end result of this addendum is that more buildings should be required to have vestibules, and this should lead to a minor energy savings. This is a mandatory requirement for the building envelope and therefore would have the same impact when used with the prescriptive, envelope tradeoff, or whole building compliance paths.

Addendum $\mathrm{k}$ adds a reference table value for R-19 batt insulation installed in metal buildings with screw-down roofs. Because this addendum only impacts the reference tables and not the actual requirements, no energy impact on any compliance path is expected from this addendum.

Addendum $\mathrm{n}$ adds instructions for dealing with solar heat gain coefficient (SHGC) credit for partially opaque permanent projections such as framing with glass or perforated metal. The standard previously allowed SHGC credit only for opaque permanent projections. Because this addendum is allowing credit for nominally equivalent partially opaque permanent projections, no energy impact for any compliance path is expected from this addendum.

Addendum o adds new climatic data for China and Taiwan to Table D-3, International Climate Data, and also corrects climate data for Malaysia and Mexico in the same table. None of this data impacts DOE's determination and therefore the energy impact in all compliance paths of this addendum is zero.

Addendum y adds the option to use the Solar Reflective Index (SRI), as determined by American Society for Testing and Materials (ASTM) E1980, when calculating credit for high albedo roofs. Because this is simply an additional alternative to use of the solar reflectance and thermal emittance and the values chosen for SRI were chosen to match the requirements for solar reflectance and thermal emittance, no energy savings for any compliance path are expected from this addendum.

Addendum ad adds the Cool Roof Rating Council as the example for a nationally recognized accreditation organization for cool roofs and adds ASTM C1549 as an optional solar reflectance test method, while deleting ASTM E1 175 and C835 as test methods due to their limited availability to the general public through laboratories. Because ASTM C1549 is considered to be equivalent to the two deleted test methods, there should be no energy impact on any compliance path from this addendum.

Addendum aj rewrites the high albedo roof credit section to replace the table of roof insulation multipliers with actual roof insulation requirements. This addendum makes editorial changes to an optional set of requirements and therefore the energy impact on all compliance paths of this addendum is zero.

Addendum al modifies the base assembly description and reference U-factor tables for metal building roofs in Appendix A of Standard 90.1. Addenda al also changes the nomenclature used for metal building 
roofs. Because this addendum does not change the actual requirement for metal building roofs, the energy impact for all compliance paths of this addendum is zero.

Addendum as modifies the building envelope requirements for opaque assemblies only. While most of the changes result in increased stringency, some of the changes result in reduced stringency. A detailed discussion of Addenda as is provided below in the indented paragraph and in Appendix A. Overall, this addendum is expected to directly increase the stringency of the prescriptive envelope requirements and indirectly increase the stringency of both the envelope tradeoff and whole building tradeoff, thus leading to an overall energy savings.

In this addendum, the nonresidential heated slab on grade floors changed from F- $0.84^{1}$ to F-0.86 in zones 5 and 6 . In zone 7, nonresidential heated slab on grade floors changed from F-0.84 to F-0.843, but since both of these zone 7 requirements also state R-10 for 36 inches, this appears to be simply a matter of how many digits are being shown in the different versions of the standard. Residential heated slabs in zones 4 and 5 also changed from F-0.84 to F-0.86. F-0.84 corresponds to R-10 for 36 inches. F-0.86 corresponds to R-15 for 24 inches. Comparing the 16 nonresidential and residential heated slab requirements in Standard 90.1-2007 with the Standard 90.1-2004 requirements, four show an increase in allowed F-factor by 2.4 percent (a reduction in stringency), five have the identical F-factor, and seven have a reduction in F-factor of from 9 to 12 percent (an increase in stringency). All other opaque envelope requirements (including non-heated slabs) are either identical or more stringent in Standard 90.1-2007. In practice - None of the building models contemplated for use in the determination involve heated slabs due to their infrequent usage in the general building population and due to difficulty in doing detailed simulation of heated slabs. So the impact of this change would not show up in DOE's quantitative (whole building energy use) analysis. It is anticipated, however, that the decreases in heated slab F-factor (improvements in efficiency) outweigh the increases in heated slab F-factor (degradation in efficiency). It should be noted that half the heated slab changes occur in buildings with residential spaces. This might include hotels or motels with guest rooms with heated slabs-on-grade, hospitals or nursing homes with patient rooms with heated slabs-on-grade, or high-rise apartment buildings with apartment or condominium spaces with heated slabs-on-grade. While all of these cases are allowed under Standard 90.1-2007, there is little or no information available to say how common any of these are in general construction. Requirements for all other opaque wall and roof materials either got more stringent or stayed the same under 90.12007.

Addendum at modifies the building envelope requirements for fenestration. While most of the changes result in increased stringency, some of the changes result in reduced stringency. A detailed discussion of Addenda at is provided below in the indented paragraph and in Appendix A. Overall, this addendum is expected to directly increase the stringency of the prescriptive envelope requirements and indirectly increase the stringency of both the envelope tradeoff and whole building tradeoff, thus leading to an overall energy savings.

\footnotetext{
${ }^{1} \mathrm{~F}-0.84$ refers to the F-factor of slab. F-factor is the perimeter heat loss factor for the slab-on-grade floor, expressed in $\mathrm{Btu} / \mathrm{h}-\mathrm{ft}^{2}-{ }^{\circ} \mathrm{F}$
} 
In this addendum, the $\mathrm{U}$-factor ${ }^{2}$ requirements for residential and nonresidential glazing in zones $3 \mathrm{~A}$ and $3 \mathrm{~B}$ were raised slightly from 0.57 (for fixed windows) and 0.67 (for operable windows) to values ranging from 0.60 (metal framed curtain wall and storefront) to 0.65 (nonmetal frames and metal framed other fenestration) to 0.90 (metal framed entrance doors). In all other zones, U-factor requirements were lowered, sometimes dramatically for non-metal framing, metal framing curtain wall and storefront, and metal framing all other categories. For example, in zone 2 (primarily the Gulf Coast, but also parts of west Texas, Arizona, and California), U-factor is lowered from 1.22 to values ranging from 0.70 (metal framed curtain wall and storefront) to 0.75 (nonmetal frames and metal framed other fenestration). For metal framing entrance doors, the Ufactor requirements were increased in zones 3-8 but were reduced in zones 1 and 2 . The zones ( $3 a$ and $3 b$ ) with slight increases in window $U$-factor (not including the changes in entrance doors) also showed slight decrease in maximum SHGC for low window-to-wall ratio (WWR) buildings, which would tend to counteract (in terms of annual usage) the energy impact of the change in U-factor. The higher U-factor and lower SHGC do constitute a potential fuel shift with these buildings potentially using somewhat more heating and somewhat less cooling. In general, the total amount of window area in entrance doors is believed to be relatively small and the increase in allowed U-value here is believed to be outweighed by the positive changes to other fenestration. All other fenestration requirements are either identical or more stringent in Standard 90.1-2007.

Addendum av provides clarification for the use of louvered overhangs (as opposed to completely opaque overhangs or partially opaque overhangs or perforated overhangs) in calculating SHGC credits. The requirements for louvered overhangs are that they are eligible for full credit if no sun penetrates the louvers during the peak sun angle on June 21 (in the northern hemisphere). There are pluses and minuses to this addendum. For some buildings with daylighting controls, louvers may be a very significant energy savings feature and therefore giving credit for these louvers in terms of SHGC may have a net positive impact. For other buildings, if the sun does not penetrate the louvers on June 21, but does penetrate on July 21 and creates an additional cooling load, the net impact of the louver on energy efficiency may be slightly negative. Overall, the net impact of this addendum in all envelope compliance paths is potentially slightly negative, but very hard to determine. In practice - It is unlikely that an architect or designer looking to add overhangs of any type to a building intentionally would design the overhangs to increase cooling load. Architects and designers looking at overhangs of all types are typically looking to reduce cooling loads, and this addendum simply provides designers with the option to use one more type of overhang.

\subsection{Changes to Section 6, Heating, Ventilating, and Air-Conditioning}

The heating, ventilating, and air-conditioning (HVAC) section contains two intertwined compliance paths: simple buildings (a combination of mandatory and prescriptive requirements for a specific set of systems) and complex systems (mandatory and prescriptive requirements for all other systems). This section also contains a tradeoff between economizer usage and equipment efficiency. In addition, the

\footnotetext{
${ }^{2} \mathrm{U}$-factor is also referred to as thermal transmittance and is defined as heat transmission in unit time through unit area of a material or construction and the boundary air films, induced by unit temperature difference between the environments on each side. Units of $\mathrm{U}$ are $\mathrm{Btu} / \mathrm{h}-\mathrm{ft}^{2}-{ }^{\circ} \mathrm{F}$
} 
prescriptive requirements of this section form the baseline HVAC requirements for the whole building tradeoff method in Section 11, Energy Cost Budget Method.

Addendum $\mathrm{b}$ adds definitions of single package vertical air conditioner and single package vertical heat pump and modifies the requirements for these pieces of equipment to match DOE's rulemaking on this type of equipment. Because this addendum simply implements the results of DOE's rulemaking, the energy savings of this addendum is zero in all compliance paths.

Addendum $\mathrm{f}$ raises the minimum efficiency standard for three-phase air-cooled central air conditioners and heat pumps less than $65,000 \mathrm{Btu} / \mathrm{h}$ to $13 \mathrm{SEER} / 7.7 \mathrm{HSPF}$ to be consistent with Federal minimum standards for single-phase residential equipment. The proposal also removes the product class for small duct high velocity (SDHV) equipment to be consistent with the DOE final rule. Because this addendum is simply implementing the results of a DOE rulemaking process, the impact of this addendum is assumed to be zero in all compliance paths.

Addendum $g$ amends the minimum efficiency levels of air-cooled air conditioners and heat pumps greater or equal to $65,000 \mathrm{Btu} / \mathrm{h}$ contained in Tables 6.8.1A and 6.8.1B of ASHRAE Standard 90.1-2004 to be consistent with the DOE's rulemaking for these types of equipment. Because this addendum is simply implementing the results of a DOE rulemaking process, the impact of this addendum is assumed to be zero in all compliance paths.

Addendum $\mathrm{h}$ removes the exception for data processing systems from the dead band requirement of Standard 90.1 and also removes the exception for computer rooms from the requirement prohibiting simultaneous operation of humidification and dehumidification systems. The exceptions were removed as a result of work performed for ASHRAE's publication "Thermal Guidelines for Data Processing Environments," which found that data processing and computer equipment were not as sensitive to temperature and humidity variation as previously thought. Systems that would have previously been exempt from the requirements under the exceptions will now be required to maintain dead band requirements and avoid simultaneous operation of humidification and dehumidification systems. Because this addendum removes the exceptions for these systems, the addendum is expected to achieve a modest amount of energy savings in the complex system and whole building tradeoff compliance paths.

Addendum $r$ updates the reference to Air-Conditioning and Refrigeration Institute (ARI) 340/360, "Commercial and Industrial Unitary Air Conditioning and Heat Pump Equipment." Because this addendum is simply updating a reference, no energy impact is expected in any compliance path.

Addendum s revises the reference to ASHRAE Standard 62.1, "Ventilation for Acceptable Indoor Air Quality," as well as text callouts to Standard 62.1 in Standard 90.1. This addendum can be considered either editorial (with no impact in all compliance paths) or potentially impactful in all compliance paths (because Standard 62.1-2004 has different ventilation requirements from Standard 62-1999). Standard 62.1-2004 has lower ventilation rate requirements than Standard 62-1999 for some building types, and the lower ventilation rate means that there is less outside air that must be heated or cooled, and therefore less energy used to heat or cool that air. Different ventilation requirements will lead to different energy usage by buildings and there are differences between Standards 62-1999 and 62.1-2004. However, this difference is due to not so much to a change in Standard 90.1 as to changes in Standard 62. DOE will investigate the impact of this addendum in the quantitative analysis of Standard 90.1-2007 and decide 
whether or not to include the energy savings associated with this change in Standard 62 in the overall energy savings associated with Standard 90.1.

Addendum $t$ adds an additional combustion efficiency requirement to the existing thermal efficiency requirements for boilers and replaces the existing H.I. Heating Boiler Standard with DOE's 10 CFR Part 435 Test Procedures. Because this addendum simply reiterates existing Federal standards for boilers, no energy impact is expected in any compliance path.

Addendum v adds a definition of demand controlled ventilation to Section 3.2 definitions and revises the requirements for ventilation of high-occupancy spaces to explicitly require demand control ventilation. Previously, the standard had required some means to reduce ventilation based on occupancy, but demand controlled ventilation was not specified. The threshold for demand controlled ventilation is also lowered from 100 occupants per 1,000 $\mathrm{ft}^{2}$ to 40 occupants per 1,000 $\mathrm{ft}^{2}$, indicating that this requirement will be applied in more situations in Standard 90.1-2007 than it would have been in Standard 90.1-2004. This should result in a significant energy savings in the complex systems and whole building tradeoff compliance paths associated with this addendum.

Addendum ac adds five new definitions to Section 3.2: fan brake horsepower, fan system design conditions, fan system bhp, fan system motor nameplate hp, and nameplate horsepower. Addendum ac also makes extensive changes to Section 6.5.3, Air System Design and Control, to make use of these definitions. The addendum also increases the stringency of the fan power limitation for systems that use the motor nameplate horsepower option. For simple systems with low pressure drop, the allowable fan power limitation drops from $1.2 \mathrm{hp}$ per 1,000 CFM to $1.1 \mathrm{hp}$ per 1,000 CFM for constant volume systems and from $1.7 \mathrm{hp}$ per 1,000 CFM to $1.5 \mathrm{hp}$ per 1,000 CFM for variable volume systems. For larger systems that may have larger pressure drops and that use the fan system bhp approach, the stringency difference is hard to calculate. The allowable hp per 1,000 CFM is reduced in the addendum, but an additional term accounting for pressure drop is added to the requirement. Overall, it is expected that there will be some increase in stringency in the complex system and whole building tradeoff compliance paths associated with this addendum.

Addendum ak adds a third-party certification requirement for heat rejection equipment by requiring the use of Cooling Tower Institute (CTI) STD-201, "Standard for the Certification of Water-Tower Cooling Thermal Performance." There is potentially a minor amount of energy savings in the complex systems and whole building tradeoff approaches attributable to third-party certification because an independent third party has checked the thermal performance of the cooling tower.

Addendum an raises efficiency requirements for boilers 3 years after approval by the ASHRAE Board of Directors and again 13 years after approval by the ASHRAE Board of Directors. These dates are listed as March 2, 2010, and March 2, 2020, in Standard 90.1-2007. Increases in efficiency range from 0 percent (for small boilers) to up to 5 percent improvement for intermediate sized boilers and up to 2.5 percent for large boilers. This addendum will likely produce significant energy savings in all compliance paths when the requirements become mandatory. Only the requirements that become mandatory in 2010 will be considered in the quantitative analysis.

Addendum ao adds a requirement for intermittent ignition devices for warm air unit heaters. This requirement was added in response to legislative mandates in Section 135 of the Energy Policy Act of 2005 and therefore this addendum is considered to have zero energy savings in all compliance paths. 
Addendum ar reduces the part-load fan power limitation from $15 \mathrm{hp}$ to $10 \mathrm{hp}$. This has the effect of requiring some sort of control or device that reduces fan motor demand when the static pressure setpoint is below total design static pressure, and therefore saves energy. This addendum is expected to save a significant amount of energy in the complex system and whole building tradeoff compliance paths.

\subsection{Changes to Section 7, Service Water Heating}

No changes were made to Section 7, Service Water Heating, during the creation of Standard 90.12007.

\subsection{Changes to Section 8, Power}

No changes were made to Section 8, Power, during the creation of Standard 90.1-2007.

\subsection{Changes to Section 9, Lighting}

The lighting section has mandatory requirements applicable to all compliance paths and contains two compliance paths: the building area method and the space-by-space method. In addition, the requirements of the lighting section form the baseline lighting requirements for the whole building tradeoff method in Section 11, Energy Cost Budget Method.

Addendum e modifies how luminiare wattage is calculated for track and busway type lighting fixtures by allowing use of the wattage limit of the circuit breaker or other current limiting devices in the system. Because this addendum simply offers two additional alternatives for calculating the luminaire wattage, this addendum is considered to have zero energy savings for all compliance paths.

Addendum i allows the use of the maximum labeled wattage of the luminiare as opposed to the operating input wattage of the maximum lamp/auxiliary combination for luminiares with permanently installed or remote ballasts or transformers. The stated purpose of the addendum is to provide additional flexibility, and no energy savings are expected from this addendum in any compliance path.

Addendum $\mathrm{j}$ provides editorial clarification of the exterior lighting control requirements by allowing either a combination of a photo sensor and time switch OR an astronomical time switch. Addendum $\mathrm{j}$ also requires that all time switches (not just astronomical time switches) be capable of retaining programming during loss of power for at least 10 hours. This addendum is considered to be primarily editorial, and no energy savings are expected in any compliance path.

Addendum m provides an exception that allows "furniture-mounted supplemental task lighting that is controlled by automatic shutoff' and that complies with the additional control requirements in Section 9.4.1.4(d) to be exempted from the calculation of the interior lighting power for the building. Because this addendum deals with how interior lighting power is calculated, this addendum could have minor negative impacts in all compliance paths. The impact of this is to exempt from the interior lighting power calculations any furniture-mounted task lighting that is included on the building plans. However, since furniture-mounted task lighting is rarely indicated on building plans, the effective impact is likely to be very small. In practice - While exempting furniture-mounted task lighting that is provided with automatic shutoff from the interior lighting power alone is a negative impact since it "allows" for a 
higher total lighting power to exist in the zone, deciding whether or not this addendum is an overall negative requires deciding whether the beneficial impact of requiring automatic shutoff controls on this task lighting outweighs the impact of removing such task lighting from the calculation of the base lighting power density in the building. This calculation is highly dependent on the assumed schedule of operation of furniture-mounted task lights in the building, including assumptions regarding "how well the occupants would turn off these lights in the absence of automatic lighting shutoff." In addition, we feel that the overall fraction of furniture for which furniture-mounted task lighting would be specified in the building plans is small. Overall, we would have to say that Addendum $m$ has a small, but probably unquantifiable, impact. The magnitude of any impact would be directly related to assumptions made about the quantities and schedules of task lighting that might fall under this exemption. Since neither the quantities nor schedules are controlled by Standard 90.1-2007, this simply becomes an exercise in assumptions. No building models currently envisioned for the determination get down to the detail of including furniture-mounted task lighting or how the addition of furniture-mounted controls might impact the operating hours for those task light, and if they did, the requirement that this task lighting be subjected to automatic shutoff is a requirement that exceeds the control requirements for other task lighting.

Addendum $\mathrm{p}$ modifies the exceptions related to interior lighting power to clarify that lighting for all occupants with special lighting needs, including age-related needs, and not just lighting for visually impaired persons, is excluded from the interior lighting power calculations. This addendum could have minor negative impacts in all compliance paths. The original language in the exemption only noted visual impairment. The expanded text makes it clear that age-related issues as well as medical issues other than impaired vision may require special lighting. This might include full spectrum and/or higher levels as mediation for seasonally affected disorder and other disorders. In practice - This addendum appears to have broadened the scope of exempted lighting power somewhat, although the extent of that broadening is strongly dependent on interpretation of the term "visual impairment" in the original standard. In addition, the text of this section indicates that exempted lighting must be separately controlled from the general illumination. So a table lamp or wall-mounted sconce with separate controls might be exempted. Given the explicit distinction of this special lighting from general illumination, a higher general lighting power density does not appear to be allowed under this section. The end result of this addendum appears to be primarily clarification of the term "visual impairment" that might remind users that "visual impairment" can mean many things. As such, more users might be encouraged to apply for an exception. Overall, it is likely that this addendum has a small, but probably unquantifiable, negative impact. The magnitude of any impact would be directly related to assumptions made about how much additional "visual impairment" lighting might be installed under Standard 90.1-2007. Since this quantity is not regulated in Standard 90.1-2007, this simply becomes an exercise in assumptions.

Addendum q removes the exception for off-hour control requirements for hotel/motel guest rooms. Removal of this exception implies that at least some hotel/motel guest rooms would be required to have off-hour controls, including automatic shutdown, setback, optimum start, and zone isolation. This addendum is expected to provide a minor amount of energy savings in all compliance paths.

Addendum aa adds definitions for six lighting-related terms used in Standard 90.1, including astronomical time switch, efficacy (of a lamp), eye adaptation, high-frequency electronic ballast, photosensor, and task lighting. Addendum aa also replaces the phrase "current regulators" with transformers in the discussion of installed interior lighting power and replaces the term "living unit" with the term "dwelling unit" in three places in the lighting section and Informative Appendix G. All of these 
changes are expected to improve the usability of Standard 90.1, but the energy savings attributable to this addendum are zero in all compliance paths.

Addendum ai modifies the handling of additional interior lighting power by eliminating the allowance for additional lighting power for use with visual display terminals and by modifying the allowances for retail spaces to four categories instead of two categories. The requirements for retail spaces change from 1.6 and 3.9 watts per square foot of specific display to 1.0, 1.7, 2.6, or 4.2 watts per square foot of floor area for specific categories of merchandise. The addendum makes it clear that only jewelry, crystal, and china qualify for the highest category of allowance. Most merchandise areas will fall under the lowest category, and this allowance is reduced from 1.6 to 1.0 watts per square foot. Because this lowest category is reduced, the overall impact of this addendum should be to provide some minor energy savings in the space-by-space method and whole building method compliance paths.

Addendum ap clarifies the intent of Standard 90.1-2004 for the "sales area" space type and the appropriate application of the retail additional lighting power allowances. This addendum is considered clarification only and therefore this addendum is considered to have zero energy savings. This addendum impacts only the space-by-space method and whole building compliance paths.

\subsection{Changes to Section, 10 Other Equipment}

No changes were made to Section 10, Other Equipment, during the creation of Standard 90.1-2007.

\subsection{Changes to Section 11, Energy Cost Budget Method}

Section 11, Energy Cost Budget Method, is the whole building tradeoff compliance method for Standard 90.1-2007. The mandatory and prescriptive requirements of the envelope, HVAC, service water heating, power, lighting, and other systems all provide the baseline requirements for the whole building tradeoff. In addition, specific changes to the rules of the tradeoff associated with Section 11 may also impact the stringency of this compliance path.

Addendum ab clarifies referenced sections in Section 11, Energy Cost Budget Method, and Informative Appendix G, Performance Rating Method, concerning lighting requirements. Because this is simply a clarification of which lighting requirements form the baseline, the energy impact of this addendum is zero.

Addendum ae changes Section 11 and Informative Appendix $G$ to clarify the way lighting power is to be modeled. An average lighting power density for each thermal block should be determined and used in the simulation model. Because this section is clarification, this addendum is considered to have zero energy savings.

Addendum am changes the minimum ventilation rates required for variable air volume (VAV) systems with reheat in Section 11, Energy Cost Budget Method, and Informative Appendix G, Performance Rating Method. The energy impact of this addendum is zero. 


\subsection{Changes to Section 12, Normative References}

Addendum d updates the references to seven ASTM and four National Fenestration Rating Council (NFRC) standards, and deletes references to two ASTM and three NFRC standards that no longer apply to Standard 90.1. This addendum has no energy savings in any compliance path.

Addendum 1 updates the reference to ANSI/ASHRAE Standard 140, "Standard Method of Test for the Evaluation of Building Energy Analysis Computer Programs." Because this addendum only impacts reference documents, no energy impact is expected from this addendum for any compliance path.

Addendum x updates the reference and callouts for ASTM C1549, "Standard Test Method for Determination of Solar Reflectance Near Ambient Temperature Using a Portable Solar Reflectometer," and deletes references to two other ASTM standards (E1175 and C835). Because this addendum only updates references, no energy impact in any compliance path is expected.

Addendum aq updates the reference years of two CTI test standards: CTI ATC-105 and CTI STD201. This addendum is considered editorial only and to have zero energy savings for any compliance path.

\subsection{Changes to Informative Appendix E, Informative References}

No changes were made to Informative Appendix E, Informative References, during the creation of Standard 90.1-2007.

\subsection{Changes to Informative Appendix F, Addenda Description Information}

Informative Appendix F, Addenda Description Information, is simply a list of all addenda to Standard 90.1-2004 processed during the creation of Standard 90.1-2007.

\subsection{Changes to Informative Appendix G, Performance Rating Method}

Informative Appendix G, Performance Rating Method, is the basis of the energy points associated with the U.S. Green Building Council Leadership in Energy and Environmental Design rating system. While the addenda to this appendix may have impact beyond Standard 90.1, they have no impact on compliance with Standard 90.1.

Addenda a makes a number of changes to Informative Appendix G, Performance Rating Method, and one change to Section 3.2, Definitions. The change to the definitions was the addition of a definition for unmet load hours. The changes to Appendix G include the following:

- addition of a requirement that the simulation program be tested by ANSI/ASHRAE Standard 140,

- addition of a requirement that spreadsheets or other documentation of assumptions be used if the simulation program does not specifically model the functionality of installed systems, 
- addition of specific guidance on how to model un-insulated envelope assemblies such as parapets, projecting balconies, and concrete floor beams over parking garages

- removal of an exclusion of multi-family apartment and hotel/motel guest room lighting from the overall calculation of baseline and proposed building performance,

- modification of the baseline building envelope to require that glazing be distributed in the same orientations and proportions in the baseline as in the proposed design (as opposed to requiring the baseline building to have uniformly distributed glazing),

- revision of the baseline HVAC system types to be assumed for various sizes of nonresidential buildings (revisions were made only to the sizes categories, with the category of $75,000 \mathrm{ft}^{2}$ being reduced to $25,000 \mathrm{ft}^{2}$ ), with the end result that fewer buildings will be required to use packaged single zone-AC systems and more buildings will be required to use packaged VAV with reheat,

- modification to the supply air temperature reset requirement for systems 5-8,

- addition of a requirement for calculation of recirculating pump energy usage for hot water systems,

- addition of new guidance for dealing with hot water loads, and

- addition of new guidance for dealing with other baseline loads.

The changes made clarify Appendix $G$ and expand its guidance to systems that were previously given little coverage in Appendix G. While some of the changes may have positive impacts on energy efficiency (for example, the change in baseline systems from packaged single zone reheat to packaged VAV for some buildings), Appendix G is informative only and not part of Standard 90.1. Therefore, the energy impact of this addendum is assumed to be zero.

Addenda $u$ provides additional modeling guidance for Baseline HVAC systems in Informative Appendix G, Performance Rating Method. Because this addendum only impacts informative Appendix $\mathrm{G}$, the impact of this addendum is assumed to be zero.

Addenda ag clarifies that only HVAC fans that provide outdoor air for ventilation need to be modeled as running continuously in the rules for proposed building design in Informative Appendix G, Performance Rating Method. Because Appendix G is informative and not part of Standard 90.1, the energy impact of this addendum is zero.

Addenda ah clarifies assumptions for the baseline building in Informative Appendix G, Performance Rating Method, if condenser heat recovery for hot water is required. Because Appendix G is informative and not part of Standard 90.1, the energy impact of this addendum is zero. 



\subsection{Evaluation of Addenda by Topic and for Inclusion in the Quantitative Analysis}

The following tables were prepared to show the addenda by topic or section of the standard. These tables are also annotated to categorize the changes that can be readily incorporated into DOE's quantitative analysis, those that could possibly be incorporated into DOE's quantitative analysis (assuming suitable building models are available), and those that cannot be readily incorporated into DOE's quantitative analysis, to indicate which addenda are suitable for inclusion in the quantitative determination, which addenda might be suitable for inclusion in the quantitative determination, and which addenda are not suitable for inclusion in the quantitative determination.

\subsection{Envelope Addenda}

Table 6.1. Envelope Addenda

\begin{tabular}{|c|c|c|c|}
\hline $\begin{array}{l}\text { Addenda to } \\
90.1-2004\end{array}$ & $\begin{array}{l}\text { Included in DOE's } \\
\text { quantitative building } \\
\text { simulation analysis }\end{array}$ & Section(s) Affected & Description of Changes \\
\hline $90.1 \mathrm{c}$ & Possible & 5. Building Envelope & $\begin{array}{l}\text { This addendum revises the definition of building entrance to } \\
\text { include vestibules and clarifies the requirements and exceptions } \\
\text { for vestibules in Section 5.4.3.4. }\end{array}$ \\
\hline $90.1 \mathrm{k}$ & No & Informative Appendix A & $\begin{array}{l}\text { This addendum revises Table A } 2.3 \text { to add U-factors for screw- } \\
\text { down roofs with R-19 insulation. }\end{array}$ \\
\hline $90.1 \mathrm{n}$ & No & 5. Building Envelope & $\begin{array}{l}\text { This addendum revises Section 5.5.4.4.1 to provide an exception } \\
\text { to allow a user to take credit for partially opaque overhangs } \\
\text { towards compliance with the maximum SHGC requirements. }\end{array}$ \\
\hline $90.1 \mathrm{y}$ & No & $\begin{array}{l}\text { 5. Envelope, } 12 . \text { Normative } \\
\text { References, and } \\
\text { Informative Appendix G }\end{array}$ & $\begin{array}{l}\text { This addendum adds a reference and method of test for deriving } \\
\text { SRI (ASTM Test Method E, 1980) for high albedo roofs. The } \\
\text { changes in the standard were in both Section } 5 \text { and Informative } \\
\text { Appendix G. }\end{array}$ \\
\hline $90.1 \mathrm{ad}$ & No & 5. Building Envelope & $\begin{array}{l}\text { This addendum changes the exception to Section } 5.3 .1 .1 \text { to add a } \\
\text { requirement that the values for solar reflectance and thermal } \\
\text { emittance be determined by a laboratory accredited by a } \\
\text { nationally recognized accreditation organization, such as the } \\
\text { Cool Roof Rating Council. }\end{array}$ \\
\hline 90.1 aj & No & 5. Building Envelope & $\begin{array}{l}\text { This addendum modifies the exception to Section 5.5.3.1 by } \\
\text { adding the ASTM Test Method E 1980-Standard Practice for } \\
\text { Calculating Solar Reflectance Index (SRI) of Horizontal and } \\
\text { Low Sloped Opaque Surfaces. }\end{array}$ \\
\hline $90.1 \mathrm{al}$ & No & Normative Appendix A & $\begin{array}{l}\text { This addendum corrects the terminology used in Section A2.3 } \\
\text { for metal building roofs. }\end{array}$ \\
\hline 90.1 as & Yes & 5. Building Envelope & $\begin{array}{l}\text { This addendum modifies the opaque assembly requirements in } \\
\text { Tables 5.5-1 through 5.5-8. }\end{array}$ \\
\hline 90.1 at & Yes & 5. Building Envelope & $\begin{array}{l}\text { This addendum modifies the fenestration requirements in Tables } \\
5.5-1 \text { through } 5.5-8 \text {. }\end{array}$ \\
\hline $90.1 \mathrm{av}$ & No & 5. Building Envelope & $\begin{array}{l}\text { This addendum adds an exception to Section 5.5.4.4.1 to allow } \\
\text { credit for overhangs composed of open louvers toward } \\
\text { compliance with the maximum SHGC requirements. }\end{array}$ \\
\hline
\end{tabular}




\subsection{HVAC Addenda}

Table 6.2. HVAC Addenda

\begin{tabular}{|c|c|c|c|}
\hline $\begin{array}{l}\text { Addenda to } \\
\text { 90.1-2004 }\end{array}$ & $\begin{array}{l}\text { Included in DOE's } \\
\text { quantitative } \\
\text { building } \\
\text { simulation analysis }\end{array}$ & Section(s) Affected & Description of Changes \\
\hline $90.1 b$ & No & $\begin{array}{l}\text { 6. Heating, Ventilating, and } \\
\text { Air Conditioning }\end{array}$ & $\begin{array}{l}\text { Revises Table } 6.8 .1 \mathrm{D} \text { and adds a definition for single-package } \\
\text { vertical air-conditioner and single-package vertical heat pump. }\end{array}$ \\
\hline $90.1 \mathrm{f}$ & No & $\begin{array}{l}\text { 6. Heating, Ventilating, and } \\
\text { Air Conditioning }\end{array}$ & $\begin{array}{l}\text { This addendum modifies Tables } 6.8 .1 \mathrm{~A} \text { and } 6.8 .1 \mathrm{~B} \text { by raising the } \\
\text { minimum efficiency for three-phase air-cooled central conditioners } \\
\text { and heat pumps to be consistent with federal minimum standards. }\end{array}$ \\
\hline $90.1 \mathrm{~g}$ & No & $\begin{array}{l}\text { 6. Heating, Ventilating, and } \\
\text { Air Conditioning }\end{array}$ & $\begin{array}{l}\text { This addendum amends the minimum efficiency levels of air- } \\
\text { cooled air conditioners and heat pumps in Tables } 6.8 .1 \mathrm{~A} \text { and } \\
\text { 6.8.1B to be consistent with federal minimum standards. }\end{array}$ \\
\hline $90.1 \mathrm{~h}$ & No & $\begin{array}{l}\text { 6. Heating, Ventilating, and } \\
\text { Air Conditioning }\end{array}$ & $\begin{array}{l}\text { This addendum revises the exceptions to Sections } 6.4 .3 .1 .2 \text { and } \\
6.4 .3 .6 \text { by removing data processing centers from having specific } \\
\text { exceptions on temperature and humidification dead bands. }\end{array}$ \\
\hline $90.1 \mathrm{q}$ & Possible & $\begin{array}{l}\text { 6. Heating, Ventilating, and } \\
\text { Air Conditioning }\end{array}$ & $\begin{array}{l}\text { This addendum removes Exception (a) to Section } 6.4 .3 .2 \text { for } \\
\text { HVAC systems serving hotel/motel rooms and guest rooms. }\end{array}$ \\
\hline $90.1 \mathrm{~s}$ & Possible & $\begin{array}{l}\text { 6. Heating, Ventilating, and } \\
\text { Air Conditioning and } 12 \text {. } \\
\text { Normative References }\end{array}$ & $\begin{array}{l}\text { This addendum updates language in the standard based on } \\
\text { differences between Standard 62-1999 and 62.1-2004. The } \\
\text { reference has also been updated. }\end{array}$ \\
\hline $90.1 \mathrm{t}$ & No & $\begin{array}{l}\text { 6. Heating, Ventilating, and } \\
\text { Air Conditioning and } 12 . \\
\text { Normative References }\end{array}$ & $\begin{array}{l}\text { This addendum changes Table } 6.8 .1 \mathrm{~F} \text { to add an additional } \\
\text { requirement of combustion efficiency to the current requirement of } \\
\text { thermal efficiency for boilers, which will increase minimum } \\
\text { efficiency. The reference in Section } 12 \text { has also been changed to } \\
\text { reflect the change in the table. }\end{array}$ \\
\hline $90.1 \mathrm{v}$ & No & $\begin{array}{l}\text { 6. Heating, Ventilating, and } \\
\text { Air Conditioning }\end{array}$ & $\begin{array}{l}\text { This addendum modifies the provisions of Section 6.4.3.8 to allow } \\
\text { for demand control ventilation. }\end{array}$ \\
\hline $90.1 \mathrm{ac}$ & Yes & $\begin{array}{l}\text { 3. Definitions and } \\
6 . \text { Heating, Ventilating, and } \\
\text { Air Conditioning }\end{array}$ & $\begin{array}{l}\text { This addendum modifies the fan power limitation requirements in } \\
\text { Section 6.5.3. }\end{array}$ \\
\hline $90.1 \mathrm{ak}$ & No & $\begin{array}{l}\text { Table } 6.2 .1 \mathrm{G} \text {, Performance } \\
\text { Requirements for Heat } \\
\text { Rejection Equipment, and } \\
\text { Section } 6.2 .1\end{array}$ & $\begin{array}{l}\text { This addendum changes Table } 6.2 .1 \mathrm{G} \text { to add requirements for } \\
\text { cooling towers to be tested to CTI test procedures and to update the } \\
\text { corresponding references in Section } 6.2 .1 \text {. }\end{array}$ \\
\hline 90.1 an & Yes & $\begin{array}{l}\text { 6. Heating, Ventilating, and } \\
\text { Air Conditioning }\end{array}$ & $\begin{array}{l}\text { This addendum modifies the equipment efficiency requirements for } \\
\text { commercial boilers in Table 6.8.1F. }\end{array}$ \\
\hline 90.1 aо & No & $\begin{array}{l}\text { 6. Heating, Ventilating, and } \\
\text { Air Conditioning }\end{array}$ & $\begin{array}{l}\text { This addendum adds a footnote for increasing unit heater } \\
\text { efficiency requirements (requiring intermittent ignition devices, } \\
\text { power venting, or flue dampers) to comply with federal law. }\end{array}$ \\
\hline $90.1 \mathrm{ar}$ & Possible & 6. Mechanical & $\begin{array}{l}\text { This addendum lowers the part-load fan power limitation from } 15 \\
\text { HP to } 10 \mathrm{HP} \text { in Section 6.5.3.2.1. }\end{array}$ \\
\hline
\end{tabular}




\subsection{Service Water Heating Addenda}

No addenda were processed for the Service Water Heating section.

\subsection{Power Addenda}

No addenda were processed for the Power section.

\subsection{Lighting Addenda}

Table 6.3. Lighting Addenda

\begin{tabular}{|c|c|c|c|}
\hline $\begin{array}{l}\text { Addenda } \\
\text { to } \\
90.1-2004\end{array}$ & $\begin{array}{l}\text { Suitable for } \\
\text { Inclusion in } \\
\text { Quantitative } \\
\text { Analysis }\end{array}$ & Section(s) Affected & Description of Changes \\
\hline $90.1 \mathrm{e}$ & No & 9. Lighting & $\begin{array}{l}\text { This addendum recognizes that track and busway type lighting } \\
\text { systems can be limited by circuit breakers and permanently } \\
\text { installed current limiters in Section 9.1.4. }\end{array}$ \\
\hline $90.1 \mathrm{i}$ & No & 9. Lighting & $\begin{array}{l}\text { This addendum adds language to Section } 9.1 .4(\mathrm{~b}) \text { that allows } \\
\text { additional flexibility in assigning wattage to luminaires with multi- } \\
\text { level ballasts where other luminaire components would restrict } \\
\text { lamp size. }\end{array}$ \\
\hline $90.1 \mathrm{j}$ & No & 9. Lighting & $\begin{array}{l}\text { This addendum to Section } 9.4 .1 .3 \text { allows additional flexibility in } \\
\text { complying with the controls requirements by allowing additional } \\
\text { combinations of commonly available control equipment. }\end{array}$ \\
\hline $90.1 \mathrm{~m}$ & No & 9. Lighting & $\begin{array}{l}\text { This addendum revises the exception to Section } 9.2 .2 .3 \text { to provide } \\
\text { an option for compliance that exempts the commonly used } \\
\text { furniture mounted track lighting if it incorporates automatic } \\
\text { shutoff. }\end{array}$ \\
\hline $90.1 \mathrm{p}$ & No & 9. Lighting & $\begin{array}{l}\text { This addendum modifies Exception (g) to Section } 9.2 .2 .3 \text { to allow } \\
\text { for increased lighting for medical- and age-related issues in } \\
\text { addition to visual impairment. }\end{array}$ \\
\hline 90.1 aa & No & 9. Lighting & $\begin{array}{l}\text { This addendum modifies Section } 9.1 \text { to clarify some lighting } \\
\text { requirements. }\end{array}$ \\
\hline $90.1 \mathrm{ae}$ & No & 9. Lighting & $\begin{array}{l}\text { ECB and Appendix } G \text { clarification of how average lighting power } \\
\text { density for each thermal block should be modeled }\end{array}$ \\
\hline 90.1 ai & Yes & 9. Lighting & $\begin{array}{l}\text { This addendum modifies the interior lighting power requirements } \\
\text { for retail display lighting in Section 9.6.2. }\end{array}$ \\
\hline 90.1ap & No & 9. Lighting & $\begin{array}{l}\text { This addendum clarifies the intent of a "sales area" space in Table } \\
\text { 9.6.1. }\end{array}$ \\
\hline
\end{tabular}

\subsection{Other Equipment Addenda}

No addenda were processed for the Other Equipment section. 


\subsection{Other Section Addenda}

Table 6.4. Other Section Addenda

\begin{tabular}{|c|c|c|c|}
\hline $\begin{array}{l}\text { Addenda } \\
\text { to } \\
90.1-2004\end{array}$ & $\begin{array}{c}\text { Suitable for } \\
\text { Inclusion in } \\
\text { Quantitative } \\
\text { Analysis } \\
\end{array}$ & $\begin{array}{l}\text { Section(s) } \\
\text { Affected }\end{array}$ & Description of Changes \\
\hline $90.1 \mathrm{a}$ & No & $\begin{array}{l}\text { Informative } \\
\text { Appendix } G\end{array}$ & $\begin{array}{l}\text { This addendum clarifies how windows should be distributed in the baseline } \\
\text { simulation model and how un-insulated assemblies should be treated in the } \\
\text { baseline simulation model, increases the size range for the use of packaged } \\
\text { VAV systems in the baseline model, and provides more detail on how service } \\
\text { hot-water systems should be modeled. Many of these changes may affect the } \\
\text { ultimate performance rating of buildings using Appendix G. In addition, a } \\
\text { reference was added to ASHRAE Standard } 140 \text { for the method of testing } \\
\text { simulation programs. }\end{array}$ \\
\hline $90.1 \mathrm{~d}$ & No & $\begin{array}{l}\text { 12. Normative } \\
\text { References }\end{array}$ & $\begin{array}{l}\text { This addendum updates the references applicable to the building envelope and } \\
\text { deletes references that are not cited in the standard. }\end{array}$ \\
\hline $90.1 \mathrm{k}$ & No & $\begin{array}{l}\text { Informative } \\
\text { Appendix A }\end{array}$ & $\begin{array}{l}\text { This addendum revises Table A } 2.3 \text { to add } \mathrm{U} \text {-factors for screw-down roofs with } \\
\text { R-19 insulation. }\end{array}$ \\
\hline 90.11 & No & $\begin{array}{l}\text { 12. Normative } \\
\text { References }\end{array}$ & This addendum updates the reference to ASHRAE Standard 140. \\
\hline 90.10 & No & $\begin{array}{l}\text { Normative } \\
\text { Appendix D }\end{array}$ & $\begin{array}{l}\text { This addendum increases the amount of international climatic data in Appendix } \\
\text { D. }\end{array}$ \\
\hline $90.1 \mathrm{r}$ & No & $\begin{array}{l}\text { 12. Normative } \\
\text { References }\end{array}$ & $\begin{array}{l}\text { This addendum updates the reference to ARI } 340 / 260 \text { from the } 2000 \text { edition to } \\
\text { the } 2004 \text { edition. }\end{array}$ \\
\hline $90.1 \mathrm{u}$ & No & $\begin{array}{l}\text { Informative } \\
\text { Appendix G }\end{array}$ & $\begin{array}{l}\text { This addendum provides guidance for complying with the intent of the baseline } \\
\text { building design for HVAC systems } 5,6,7 \text {, and } 8 \text {, which shall be modeled as } \\
\text { floor-by-floor HVAC systems. }\end{array}$ \\
\hline $90.1 \mathrm{x}$ & No & $\begin{array}{l}\text { 12. Normative } \\
\text { References and } \\
\text { Informative } \\
\text { Appendix G }\end{array}$ & $\begin{array}{l}\text { This addendum updates the normative references in Section } 12 \text { and Informative } \\
\text { Appendix G for ATM- } 02 \text { to ATM- } 04 \text {. }\end{array}$ \\
\hline $90.1 \mathrm{ab}$ & No & $\begin{array}{l}\text { 11. Energy Cost } \\
\text { Budget Method } \\
\text { and Informative } \\
\text { Appendix G }\end{array}$ & $\begin{array}{l}\text { This addendum corrects the referenced section in Tables } 11.3 .1 \text { and G3.1; } \\
\text { Heating, Ventilating, and Air Conditioning to Sections 9.1.3, 9.1.4, and 9.2. }\end{array}$ \\
\hline $90.1 \mathrm{ag}$ & No & $\begin{array}{l}\text { Informative } \\
\text { Appendix } G\end{array}$ & $\begin{array}{l}\text { This addendum clarifies that only HVAC fans that provide outdoor air for } \\
\text { ventilation need to be modeled as running continuously. }\end{array}$ \\
\hline $90.1 \mathrm{ah}$ & No & $\begin{array}{l}\text { 11. Energy Cost } \\
\text { Budget Method }\end{array}$ & $\begin{array}{l}\text { This addendum modifies the requirements in Table } 11.3 .1 \text { for condenser heat } \\
\text { recovery. }\end{array}$ \\
\hline $90.1 \mathrm{am}$ & No & $\begin{array}{l}\text { 11. Energy Cost } \\
\text { Budget Method } \\
\text { and Informative } \\
\text { Appendix G }\end{array}$ & $\begin{array}{l}\text { This addendum modifies the VAV turndown requirements in Section } 11 \text { and } \\
\text { Informative Appendix G in accordance to the requirements in Section 6.5.2.1. }\end{array}$ \\
\hline $90.1 \mathrm{aq}$ & No & $\begin{array}{l}\text { 12. Normative } \\
\text { References }\end{array}$ & This addendum updates the references to CTI documents. \\
\hline
\end{tabular}




\section{Appendix A}

\section{Detailed Evaluation of Addenda as and at for Building}

Envelope 



\section{Appendix A - Detailed Evaluation of Addenda as and at for Building Envelope}

This appendix contains a series of detailed comparison tables for fenestration and opaque envelope requirements in Standard 90.1-2004 and Standard 90.1-2007. The tables are color coded to help identify the important instances where Standard 90.1-2007 requirements are less stringent than the corresponding requirements found in Standard 90.1-2004.

- Nominally less stringent requirements for 90.1-2007 are marked in red below and bold

Nominally more stringent requirements for 90.1-2007 are marked in green below and italics

- Nominally equal requirements for 90.1-2007 are marked in yellow below.

Overall, very few envelope requirements in Standard 90.1-2007 are less stringent than the corresponding requirements in Standard 90.1-2004. Specific values that decrease from Standard 90.12004 to Standard 90.1-2007 are discussed in the text of this comparison.

Note that requirements are considered to "nominally equal" even if there is a minor difference. For example, solar heat gain coefficient (SHGC) requirements of 0.39 and 0.40 have been considered "nominally equal," as have U-factor requirements of 1.20 and 1.22. In the case of the SHGC, the difference is very small. In the case of the U-factor requirements, the difference stems from how Standard 90.1 defines single-pane glazing. 
Table A.1. Vertical Fenestration - Nonresidential

\begin{tabular}{|c|c|c|c|c|}
\hline & $90.1-2004$ & $90.1-2004$ & $90.1-2007$ & $90.1-2007$ \\
\hline Zone & U-Factor* & $\mathrm{SHGC}^{* *}$ & U-Factor $* * *$ & SHGC*** \\
\hline 1 & 1.22 & 0.25 & 1.20 all & 0.25 \\
\hline 2 & 1.22 & 0.25 & $\begin{array}{l}N M F-0.75 \\
M F C S-0.70 \\
M F E D-1.10 \\
M F O-0.75\end{array}$ & 0.25 \\
\hline $3 \mathrm{~A}, \mathrm{~B}$ & 0.57 & $0.39(10 \%), 0.25$ & $\begin{array}{l}\text { NMF }-0.65 \\
\text { MFCS - 0.60 } \\
\text { MFED - } 0.90 \\
\text { MFO - 0.65 }\end{array}$ & 0.25 \\
\hline $3 \mathrm{C}$ & 1.22 & $\begin{array}{l}0.61(10 \%), 0.39(30 \%) \\
0.34(40 \%)\end{array}$ & $\begin{array}{l}N M F-0.65 \\
M F C S-0.60 \\
M F E D-0.90 \\
M F O-0.65\end{array}$ & 0.25 \\
\hline 4 & 0.57 & 0.39 & $\begin{array}{l}N M F-0.40 \\
M F C S-0.50 \\
M F E D-0.85 \\
M F O-0.55\end{array}$ & 0.40 \\
\hline 5 & 0.57 & $0.49(10 \%), 0.39$ & $\begin{array}{l}N M F-0.35 \\
M F C S-0.45 \\
M F E D-0.80 \\
M F O-0.55\end{array}$ & 0.40 \\
\hline 6 & 0.57 & $\begin{array}{l}0.49(10 \%) \\
0.39\end{array}$ & $\begin{array}{l}N M F-0.35 \\
M F C S-0.45 \\
M F E D-0.80 \\
M F O-0.55\end{array}$ & 0.40 \\
\hline 7 & 0.57 & 0.49 & $\begin{array}{l}N M F-0.35 \\
M F C S-0.40 \\
M F E D-0.80 \\
M F O-0.45\end{array}$ & 0.45 \\
\hline 8 & 0.46 & NR & $\begin{array}{l}N M F-0.35 \\
M F C S-0.40 \\
M F E D-0.80 \\
M F O-0.45\end{array}$ & 0.45 \\
\hline
\end{tabular}

* $\quad$ Fixed Window U-Factor up to 40\% WWR- Standard 90.1-2004 also has an operable window U-factor and values up for up to 50\% WWR.

** $\quad \mathrm{SHGC}_{\text {all }}-$ Standard 90.1-2004 also has a $\mathrm{SHGC}_{\text {north }}$ that is always higher.

*** Standard 90.1-2007 has values for non-metal framing (NMF), metal framing (curtainwall/storefront) (MFCS), metal framing (entrance door) (MFED), and metal framing all other (MFO). Where all values are same, "all" is used.

$* * * * \mathrm{SHGC}_{\text {all }}$. Standard 90.1-2007 has only $\mathrm{SHGC}_{\text {all }}$ values.

NR - No requirement 
Table A.2. Vertical Fenestration - Residential

\begin{tabular}{|c|c|c|c|c|}
\hline & $90.1-2004$ & $90.1-2004$ & $90.1-2007$ & $90.1-2007$ \\
\hline Zone & U-Factor* & SHGC** & U-Factor*** & SHGC*** \\
\hline 1 & 1.22 & 0.25 & 1.20 all & 0.25 \\
\hline 2 & 1.22 & $\begin{array}{l}0.39(10 \%) \\
0.25\end{array}$ & $\begin{array}{l}N M F-0.75 \\
M F C S-0.70 \\
M F E D-1.10 \\
M F O-0.75\end{array}$ & 0.25 \\
\hline $3 \mathrm{~A}, \mathrm{~B}$ & 0.57 & $0.39(20 \%), 0.25$ & $\begin{array}{l}\text { NMF }-0.65 \\
\text { MFCS - 0.60 } \\
\text { MFED - } 0.90 \\
\text { MFO - 0.65 }\end{array}$ & 0.25 \\
\hline $3 \mathrm{C}$ & 1.22 & $\begin{array}{l}0.61(20 \%), 0.39 \\
(30 \%), \\
0.34(40 \%)\end{array}$ & $\begin{array}{l}N M F-0.65 \\
M F C S-0.60 \\
M F E D-0.90 \\
M F O-0.65\end{array}$ & 0.25 \\
\hline 4 & 0.57 & 0.39 & $\begin{array}{l}N M F-0.40 \\
M F C S-0.50 \\
M F E D-0.85 \\
M F O-0.55\end{array}$ & 0.40 \\
\hline 5 & 0.57 & $0.49(10 \%), 0.39$ & $\begin{array}{l}N M F-0.35 \\
M F C S-0.45 \\
M F E D-0.80 \\
M F O-0.55\end{array}$ & 0.40 \\
\hline 6 & 0.57 & $\begin{array}{l}0.49(10 \%) \\
0.39\end{array}$ & $\begin{array}{l}N M F-0.35 \\
M F C S-0.45 \\
M F E D-0.80 \\
M F O-0.55\end{array}$ & 0.40 \\
\hline 7 & 0.57 & 0.49 & $\begin{array}{l}N M F-0.35 \\
M F C S-0.40 \\
M F E D-0.80 \\
M F O-0.45\end{array}$ & $N R$ \\
\hline 8 & 0.46 & NR & $\begin{array}{l}N M F-0.35 \\
M F C S-0.40 \\
M F E D-0.80 \\
M F O-0.45\end{array}$ & NR \\
\hline
\end{tabular}

* Fixed Window U-Factor up to 40\% WWR- Standard 90.1-2004 also has an operable window U-factor and values up for up to $50 \%$ WWR. ** $\quad \mathrm{SHGC}_{\text {all }}-$ Standard 90.1-2004 also has a $\mathrm{SHGC}_{\text {north }}$ that is always higher.

*** Standard 90.1-2007 has values for non-metal framing (NMF), metal framing (curtainwall/storefront) (MFCS), metal framing (entrance door) (MFED), and metal framing all other (MFO). Where all values are same, "all" is used.

**** $\mathrm{SHGC}_{\text {all. }}$ Standard $90.1-2007$ has only $\mathrm{SHGC}_{\text {all }}$ values.

NR - No requirement 
Table A.3. Vertical Fenestration - Semiheated

\begin{tabular}{|c|c|c|c|c|}
\hline & $90.1-2004$ & $90.1-2004$ & $90.1-2007$ & $90.1-2007$ \\
\hline Zone & U-Factor* & SHGC** & U-Factor $* * *$ & SHGC*** \\
\hline 1 & 1.22 & NR & 1.20 all & NR \\
\hline 2 & 1.22 & NR & 1.20 all & NR \\
\hline $3 \mathrm{~A}, \mathrm{~B}$ & 1.22 & NR & 1.20 all & NR \\
\hline $3 \mathrm{C}$ & 1.22 & NR & 1.20 all & NR \\
\hline 4 & 1.22 & NR & 1.20 all & NR \\
\hline 5 & 1.22 & NR & 1.20 all & NR \\
\hline 6 & 1.22 & NR & $\begin{array}{l}N M F-0.65 \\
M F C S-0.60 \\
M F E D-0.90 \\
M F O-0.65\end{array}$ & NR \\
\hline 7 & 1.22 & NR & $\begin{array}{l}N M F-0.65 \\
M F C S-0.60 \\
M F E D-0.90 \\
M F O-0.65\end{array}$ & NR \\
\hline 8 & 1.22 & NR & $\begin{array}{l}N M F-0.65 \\
M F C S-0.60 \\
M F E D-0.90 \\
M F O-0.65\end{array}$ & NR \\
\hline
\end{tabular}

* $\quad$ Fixed Window U-Factor up to 40\% WWR- Standard 90.1-2004 also has an operable window U-factor and values up for up to 50\% WWR. ** $\quad \mathrm{SHGC}_{\text {all }}-$ Standard 90.1-2004 also has a $\mathrm{SHGC}_{\text {north }}$ that is the same for semiheated spaces.

*** Standard 90.1-2007 has values for non-metal framing (NMF), metal framing (curtainwall/storefront) (MFCS), metal framing (entrance door) (MFED), and metal framing all other (MFO). Where all values are same, "all" is used. $* * * * \mathrm{SHGC}_{\text {all }}$. Standard $90.1-2007$ has only $\mathrm{SHGC}_{\text {all }}$ values.

$\mathrm{NR}-$ No requirement

Table A.4. Opaque Envelope, Roof, U-factor - Nonresidential

\begin{tabular}{lllllll}
\hline & $90.1-2004$ & $90.1-2004$ & $90.1-2004$ & $90.1-2007$ & $90.1-2007$ & $90.1-2007$ \\
\hline Zone & Deck & MB & Attic & Deck & MB & Attic \\
\hline 1 & 0.063 & 0.065 & 0.034 & 0.063 & 0.065 & 0.034 \\
2 & 0.063 & 0.065 & 0.034 & 0.048 & 0.065 & 0.027 \\
3 & 0.063 & 0.065 & 0.034 & 0.048 & 0.065 & 0.027 \\
4 & 0.063 & 0.065 & 0.034 & 0.048 & 0.065 & 0.027 \\
5 & 0.063 & 0.065 & 0.034 & 0.048 & 0.065 & 0.027 \\
6 & 0.063 & 0.065 & 0.027 & 0.048 & 0.065 & 0.027 \\
7 & 0.063 & 0.065 & 0.027 & 0.048 & 0.065 & 0.027 \\
\hline
\end{tabular}

Deck - Insulation entirely above deck U-factor $\quad$ MB - Metal building roof U-factor

Attic - Attic and other U-factor

Table A.5. Opaque Envelope, Wall, U-factor - Nonresidential

\begin{tabular}{lllllllll}
\hline & $90.1-2004$ & $90.1-2004$ & $90.1-2004$ & $90.1-$ & $90.1-2007$ & $90.1-2007$ & $90.1-2007$ & $90.1-2007$ \\
& & & & & & \\
\hline Zone & Mass & MB & SF & WF & Mass & MB & SF & WF \\
\hline 1 & 0.580 & 0.113 & 0.124 & 0.089 & 0.580 & 0.113 & 0.124 & 0.089 \\
2 & 0.580 & 0.113 & 0.124 & 0.089 & 0.151 & 0.113 & 0.124 & 0.089 \\
3 & 0.151 & 0.113 & 0.124 & 0.089 & 0.123 & 0.113 & 0.084 & 0.089 \\
4 & 0.151 & 0.113 & 0.124 & 0.089 & 0.104 & 0.113 & 0.064 & 0.089 \\
5 & 0.123 & 0.113 & 0.084 & 0.089 & 0.090 & 0.113 & 0.064 & 0.064 \\
6 & 0.104 & 0.113 & 0.084 & 0.089 & 0.080 & 0.113 & 0.064 & 0.051 \\
7 & 0.090 & 0.057 & 0.064 & 0.089 & 0.071 & 0.057 & 0.064 & 0.051 \\
8 & 0.080 & 0.057 & 0.064 & 0.051 & 0.071 & 0.057 & 0.064 & 0.036 \\
\hline Mass - Mass wall U-factor & & & MB - Metal building wall U-factor & &
\end{tabular}


Table A.6. Opaque Envelope, Below-Grade Wall (C-factor) and Floors (U-factor) - Nonresidential

\begin{tabular}{lllllllll}
\hline & $90.1-2004$ & $90.1-2004$ & $90.1-2004$ & $\begin{array}{l}90.1- \\
2004\end{array}$ & $90.1-2007$ & $90.1-2007$ & $90.1-2007$ & $90.1-2007$ \\
\hline Zone & BGW & MassF & SJF & WFF & BGW & MassF & SJF & WFF \\
\hline 1 & 1.140 & 0.322 & 0.350 & 0.282 & 1.140 & 0.322 & 0.350 & 0.282 \\
2 & 1.140 & 0.137 & 0.052 & 0.051 & 1.140 & 0.107 & 0.052 & 0.051 \\
3 & 1.140 & 0.107 & 0.052 & 0.051 & 1.140 & 0.107 & 0.052 & 0.051 \\
4 & 1.140 & 0.107 & 0.052 & 0.051 & 1.140 & 0.087 & 0.038 & 0.033 \\
5 & 1.140 & 0.087 & 0.052 & 0.033 & 0.119 & 0.074 & 0.038 & 0.033 \\
6 & 1.140 & 0.087 & 0.038 & 0.033 & 0.119 & 0.064 & 0.038 & 0.033 \\
7 & 0.119 & 0.087 & 0.038 & 0.033 & 0.119 & 0.064 & 0.038 & 0.033 \\
8 & 0.119 & 0.064 & 0.038 & 0.033 & 0.119 & 0.057 & 0.032 & 0.033 \\
\hline \multicolumn{3}{l}{ BGW - Below-grade wall C-factor } & & & MassF - Mass floor U-factor & &
\end{tabular}

SJF - Steel-joist floor U-factor $\quad$ WFF - Wood-frame floor U-factor

Table A.7. Opaque Envelope, Slab-On-Grade Floors (F-factor) and Doors (U-factor) - Nonresidential

\begin{tabular}{lllllllll}
\hline & $90.1-2004$ & $90.1-2004$ & $90.1-2004$ & $\begin{array}{l}90.1- \\
2004\end{array}$ & $90.1-2007$ & $90.1-2007$ & $90.1-2007$ & $90.1-2007$ \\
\hline Zone & US & HS & SD & NSD & US & HS & SD & NSD \\
\hline 1 & 0.730 & 1.020 & 0.700 & 1.450 & 0.730 & 1.020 & 0.700 & 1.450 \\
2 & 0.730 & 1.020 & 0.700 & 1.450 & 0.730 & 1.020 & 0.700 & 1.450 \\
3 & 0.730 & 1.020 & 0.700 & 1.450 & 0.730 & 0.900 & 0.700 & 1.450 \\
4 & 0.730 & 0.950 & 0.700 & 1.450 & 0.730 & 0.860 & 0.700 & $0.500^{*}$ \\
5 & 0.730 & 0.840 & 0.700 & 1.450 & 0.730 & $\mathbf{0 . 8 6 0}$ & 0.700 & 0.500 \\
6 & 0.730 & 0.840 & 0.700 & 0.500 & 0.540 & $\mathbf{0 . 8 6 0}$ & 0.700 & 0.500 \\
7 & 0.730 & 0.840 & 0.700 & 0.500 & 0.540 & $\mathbf{0 . 8 4 3}$ & 0.500 & 0.500 \\
8 & 0.540 & 0.780 & 0.500 & 0.500 & 0.520 & 0.688 & 0.500 & 0.500 \\
\hline US - Unheated slab F-factor & & & HS - Heated slab F-factor & & & \\
SD - Swinging door U-factor & & & NSD - Non-swinging door U-factor & & &
\end{tabular}

Table A.8. Opaque Envelope, Roof, U-factor - Residential

\begin{tabular}{lllllll}
\hline & $90.1-2004$ & $90.1-2004$ & $90.1-2004$ & $90.1-2007$ & $90.1-2007$ & $90.1-2007$ \\
\hline Zone & Deck & MB & Attic & Deck & MB & Attic \\
\hline 1 & 0.063 & 0.065 & 0.027 & 0.048 & 0.065 & 0.027 \\
2 & 0.063 & 0.065 & 0.027 & 0.048 & 0.065 & 0.027 \\
3 & 0.063 & 0.065 & 0.027 & 0.048 & 0.065 & 0.027 \\
4 & 0.063 & 0.065 & 0.027 & 0.048 & 0.065 & 0.027 \\
5 & 0.063 & 0.065 & 0.027 & 0.048 & 0.065 & 0.027 \\
7 & 0.063 & 0.065 & 0.027 & 0.048 & 0.065 & 0.027 \\
8 & 0.063 & 0.065 & 0.027 & 0.048 & 0.065 & 0.027 \\
\hline
\end{tabular}

Deck - Insulation entirely above deck U-factor $\quad \mathrm{MB}$ - Metal building roof U-factor

Attic - Attic and other U-factor 
Table A.9. Opaque Envelope, Wall, U-factor - Residential

\begin{tabular}{lllllllll}
\hline & $90.1-2004$ & $90.1-2004$ & $90.1-2004$ & $\begin{array}{l}90.1- \\
2004\end{array}$ & $90.1-2007$ & $90.1-2007$ & $90.1-2007$ & $90.1-2007$ \\
\hline Zone & Mass & MB & SF & WF & Mass & MB & SF & WF \\
\hline 1 & 0.151 & 0.113 & 0.124 & 0.089 & 0.151 & 0.113 & 0.124 & 0.089 \\
2 & 0.151 & 0.113 & 0.124 & 0.089 & 0.123 & 0.113 & 0.064 & 0.089 \\
3 & 0.123 & 0.113 & 0.084 & 0.089 & 0.104 & 0.113 & 0.064 & 0.089 \\
4 & 0.104 & 0.113 & 0.064 & 0.089 & 0.090 & 0.113 & 0.064 & 0.064 \\
5 & 0.090 & 0.057 & 0.064 & 0.089 & 0.080 & 0.057 & 0.064 & 0.051 \\
6 & 0.090 & 0.057 & 0.064 & 0.064 & 0.071 & 0.057 & 0.064 & 0.051 \\
7 & 0.080 & 0.057 & 0.064 & 0.051 & 0.071 & 0.057 & 0.042 & 0.051 \\
8 & 0.071 & 0.057 & 0.055 & 0.051 & 0.052 & 0.057 & 0.037 & 0.036 \\
\hline Mass - Mass wall U-factor & & & MB - Metal building wall U-factor & &
\end{tabular}

Table A.10. Opaque Envelope, Below-Grade Wall (C-factor) and Floors (U-factor) - Residential

\begin{tabular}{|c|c|c|c|c|c|c|c|c|}
\hline & $90.1-2004$ & $90.1-2004$ & $90.1-2004$ & $\begin{array}{l}90.1- \\
2004\end{array}$ & $90.1-2007$ & $90.1-2007$ & $90.1-2007$ & $90.1-2007$ \\
\hline Zone & BGW & MassF & SJF & WFF & BGW & MassF & SJF & WFF \\
\hline 1 & 1.140 & 0.322 & 0.350 & 0.282 & 1.140 & 0.322 & 0.350 & 0.282 \\
\hline 2 & 1.140 & 0.107 & 0.052 & 0.051 & 1.140 & 0.087 & 0.052 & 0.033 \\
\hline 3 & 1.140 & 0.087 & 0.052 & 0.033 & 1.140 & 0.087 & 0.052 & 0.033 \\
\hline 4 & 1.140 & 0.087 & 0.038 & 0.033 & 0.119 & 0.074 & 0.038 & 0.033 \\
\hline 5 & 1.140 & 0.074 & 0.038 & 0.033 & 0.119 & 0.064 & 0.038 & 0.033 \\
\hline 6 & 0.119 & 0.064 & 0.038 & 0.033 & 0.119 & 0.057 & 0.032 & 0.033 \\
\hline 7 & 0.119 & 0.064 & 0.038 & 0.033 & 0.092 & 0.051 & 0.032 & 0.033 \\
\hline 8 & 0.119 & 0.057 & 0.032 & 0.033 & 0.075 & 0.051 & 0.032 & 0.033 \\
\hline
\end{tabular}

Table A.11. Opaque Envelope, Slab-On-Grade Floors (F-factor) and Doors (U-factor) - Residential

\begin{tabular}{lllllllll}
\hline & $90.1-2004$ & $90.1-2004$ & $90.1-2004$ & $\begin{array}{l}90.1- \\
2004\end{array}$ & $90.1-2007$ & $90.1-2007$ & $90.1-2007$ & $90.1-2007$ \\
\hline Zone & US & HS & SD & NSD & US & HS & SD & NSD \\
\hline 1 & 0.730 & 1.020 & 0.700 & 1.450 & 0.730 & 1.020 & 0.700 & 1.450 \\
2 & 0.730 & 1.020 & 0.700 & 1.450 & 0.730 & 1.020 & 0.700 & 0.500 \\
3 & 0.730 & 1.020 & 0.700 & 0.500 & 0.730 & 0.900 & 0.700 & 0.500 \\
4 & 0.730 & 0.840 & 0.700 & 0.500 & 0.540 & $\mathbf{0 . 8 6 0}$ & 0.700 & 0.500 \\
5 & 0.730 & 0.840 & 0.700 & 0.500 & 0.540 & $\mathbf{0 . 8 6 0}$ & 0.500 & 0.500 \\
6 & 0.730 & 0.780 & 0.500 & 0.500 & 0.520 & 0.688 & 0.500 & 0.500 \\
7 & 0.540 & 0.780 & 0.500 & 0.500 & 0.520 & 0.688 & 0.500 & 0.500 \\
8 & 0.520 & 0.780 & 0.500 & 0.500 & 0.510 & 0.688 & 0.500 & 0.500 \\
\hline US - Unheated slab F-factor & & & HS - Heated slab F-factor & & & &
\end{tabular}


Table A.12. Opaque Envelope, Roof, U-factor - Semi heated

\begin{tabular}{lllllll}
\hline & $90.1-2004$ & $90.1-2004$ & $90.1-2004$ & $90.1-2007$ & $90.1-2007$ & $90.1-2007$ \\
\hline Zone & Deck & MB & Attic & Deck & MB & Attic \\
\hline 1 & 1.282 & 1.280 & 0.614 & 0.218 & 1.280 & 0.081 \\
2 & 0.218 & 0.167 & 0.081 & 0.218 & 0.167 & 0.081 \\
3 & 0.218 & 0.097 & 0.081 & 0.173 & 0.097 & 0.053 \\
4 & 0.218 & 0.097 & 0.081 & 0.173 & 0.097 & 0.053 \\
5 & 0.173 & 0.097 & 0.053 & 0.119 & 0.097 & 0.053 \\
6 & 0.173 & 0.097 & 0.053 & 0.093 & 0.097 & 0.034 \\
7 & 0.173 & 0.097 & 0.053 & 0.093 & 0.097 & 0.034 \\
8 & 0.093 & 0.072 & 0.034 & 0.063 & 0.072 & 0.034 \\
\hline
\end{tabular}

Deck - Insulation entirely above deck U-factor

Attic - Attic and other U-factor

Table A.13. Opaque Envelope, Wall, U-factor - Semi heated

\begin{tabular}{lllllllll}
\hline & $90.1-2004$ & $90.1-2004$ & $90.1-2004$ & $\begin{array}{l}90.1- \\
2004\end{array}$ & $90.1-2007$ & $90.1-2007$ & $90.1-2007$ & $90.1-2007$ \\
\hline Zone & Mass & MB & SF & WF & Mass & MB & SF & WF \\
\hline 1 & 0.580 & 1.180 & 0.352 & 0.292 & 0.580 & 1.180 & 0.352 & 0.292 \\
2 & 0.580 & 0.184 & 0.352 & 0.292 & 0.580 & 0.184 & 0.124 & 0.089 \\
3 & 0.580 & 0.184 & 0.352 & 0.089 & 0.580 & 0.184 & 0.124 & 0.089 \\
4 & 0.580 & 0.134 & 0.124 & 0.089 & 0.580 & 0.134 & 0.124 & 0.089 \\
5 & 0.580 & 0.123 & 0.124 & 0.089 & 0.151 & 0.123 & 0.124 & 0.089 \\
6 & 0.580 & 0.113 & 0.124 & 0.089 & 0.151 & 0.113 & 0.124 & 0.089 \\
7 & 0.580 & 0.113 & 0.124 & 0.089 & 0.123 & 0.113 & 0.124 & 0.089 \\
8 & 0.151 & 0.113 & 0.124 & 0.089 & 0.104 & 0.113 & 0.084 & 0.089 \\
\hline Mass - Mass wall U-factor & & & & MB - Metal building wall U-factor & &
\end{tabular}

Table A.14. Opaque Envelope, Below-Grade Wall (C-factor) and Floors (U-factor) - Semi heated

\begin{tabular}{lllllllll}
\hline & $90.1-2004$ & $90.1-2004$ & $90.1-2004$ & $90.1-$ & $90.1-2007$ & $90.1-2007$ & $90.1-2007$ & $90.1-2007$ \\
\hline Zone & BGW & MassF & SJF & WFF & BGW & MassF & SJF & WFF \\
\hline 1 & 1.140 & 0.322 & 0.350 & 0.282 & 1.140 & 0.322 & 0.350 & 0.282 \\
2 & 1.140 & 0.322 & 0.350 & 0.282 & 1.140 & 0.322 & 0.069 & 0.066 \\
3 & 1.140 & 0.322 & 0.069 & 0.282 & 1.140 & 0.322 & 0.069 & 0.066 \\
4 & 1.140 & 0.322 & 0.069 & 0.066 & 1.140 & 0.137 & 0.069 & 0.066 \\
5 & 1.140 & 0.322 & 0.069 & 0.066 & 1.140 & 0.137 & 0.052 & 0.051 \\
6 & 1.140 & 0.322 & 0.069 & 0.066 & 1.140 & 0.137 & 0.052 & 0.051 \\
7 & 1.140 & 0.137 & 0.052 & 0.066 & 1.140 & 0.107 & 0.052 & 0.051 \\
8 & 1.140 & 0.137 & 0.052 & 0.066 & 1.140 & 0.087 & 0.052 & 0.033 \\
\hline BGW - Below-grade wall C-factor & & & MassF - Mass floor U-factor & &
\end{tabular}


Table A.15. Opaque Envelope, Slab-On-Grade Floors (F-factor) and Doors (U-factor) - Semi heated

\begin{tabular}{lllllllll}
\hline & $90.1-2004$ & $90.1-2004$ & $90.1-2004$ & $90.1-$ & $90.1-2007$ & $90.1-2007$ & $90.1-2007$ & $90.1-2007$ \\
& & HS & SD & NSD & US & HS & SD & NSD \\
\hline Zone & US & HS & 1.020 & 0.700 & 1.450 & 0.730 & 1.020 & 0.700 \\
\hline 1 & 0.730 & 1.020 & 0.700 & 1.450 & 0.730 & 1.020 & 0.700 & 1.450 \\
2 & 0.730 & 1.020 & 0.700 & 1.450 & 0.730 & 1.020 & 0.700 & 1.450 \\
3 & 0.730 & 1.020 & 0.700 & 1.450 & 0.730 & 1.020 & 0.700 & 1.450 \\
4 & 0.730 & 1.020 & 0.700 & 1.450 & 0.730 & 1.020 & 0.700 & 1.450 \\
5 & 0.730 & 1.020 & 0.700 & 1.450 & 0.730 & 1.020 & 0.700 & 1.450 \\
6 & 0.730 & 1.020 & 0.700 & 1.450 & 0.730 & 0.900 & 0.700 & 1.450 \\
7 & 0.730 & 0.950 & 0.700 & 1.450 & 0.730 & 0.900 & 0.700 & 0.500 \\
8 & 0.730 & & & & HS - Heated slab F-factor & &
\end{tabular}





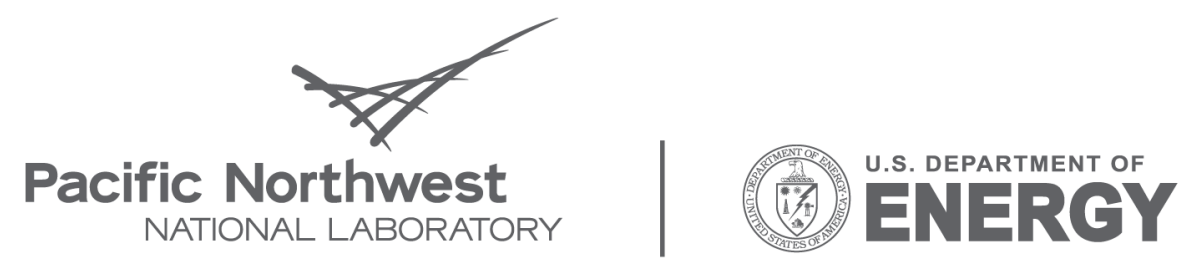

Proudly Operated by Battelle Since 1965

902 Battelle Boulevard

P.O. Box 999

Richland, WA 99352

1-888-375-PNNL (7665)

www.pnl.gov 